\title{
Integrated Upper Ordovician-lower Silurian biostratigraphy of the Grötlingbo-1 core section, Sweden
}

Peep Männik, David K. Loydell, Viiu Nestor and Jaak Nõlvak

\begin{abstract}
The biostratigraphical data obtained from the Grötlingbo-1 core section (southern Gotland, Sweden) enable recognition of most of the regional stages known from the Sandbian (Upper Ordovician) to lower Sheinwoodian (Wenlock, Silurian) interval in the East Baltic. The strata corresponding to the Upper Ordovician Keila-Nabala stages have markedly reduced thicknesses in the Grötlingbo-1 core section. Gaps of considerable duration were recognised in some parts of the section: lithological evidence suggest that only lower part of the Pirgu Stage (corresponds to all or part of the Jonstorp Fm.) is represented in the section; in the Llandovery, strata corresponding to the Aspelundia? fluegeli and Distomodus staurognathoides conodont biozones, and to the Pterospathodus eopennatus Conodont Zone (equivalent to the Conochitina alargada and Eisenackitina dolioliformis chitinozoan zones) are missing. Graptolites from the core indicate that the sedimentary record above the Aeronian to middle Telychian gap recommences in the lower part of the Oktavites spiralis Graptolite Zone. Co-occurrences of conodonts, graptolites and chitinozoans agree with earlier data suggesting correlation between the lower boundaries of the Cyrtograptus lapworthi GZ and Pt. am. amorphognathoides $\mathrm{CZ}$, and between the lower and middle parts of the Ireviken Event and the upper Cyrt. murchisoni GZ.
\end{abstract}

\section{Introduction}

Gotland is a classical region of Silurian geology, for both Baltoscandia and globally. However, the majority of studies on the island have been based on the isolated, although numerous outcrop sections. Due to the limited number of core sections available, little is known about the subsurface geology of the region. One of these rare core sections is the Grötlingbo-1 (known also as Grötlingboborrningen-1: e.g. Eriksson \& Hagenfeldt 1997) section. Some information about the section, or parts of it, is available in several earlier publications. A series of small samples $(25 \mathrm{~g}$ each) from the middle Ordovician interval of the section was studied for microflora (baltisphaerids) by Kjellström (1971a,b). Snäll (1977) investigated the distribution and composition of bentonites, Eriksson and Hagenfeldt (1997) provided information about acritarch assemblages in the lower Silurian and Grahn (1982; revised data in Grahn \& Nõlvak 2010) about the Ordovician chitinozoans in the section. Sandbian-lower Katian lithologies and chemostratigraphy are briefly discussed in Ainsaar \& Meidla (2001).

In recent decades, stratigraphical studies in the eastern Baltic have concentrated on integrating the biostratigraphy of different fossil groups with the aim of increasing the resolution and reliability of dating and correlation of strata, particularly between sections originating from different environments (facies). Of particular interest, and importance, have been studies of the co-occurrences of graptolites, chitinozoans and conodonts (Loydell, Kaljo \& Männik 1998; Loydell, Männik \& Nestor 2003; Loydell, Nestor \& Männik 2010). In this paper we will discuss co-occurrences of these fossils (particularly the conodonts and chitinozoans) 
recorded in the Grötlingbo-1 core section. The interval studied by us corresponds to the Upper Ordovician (Sandbian) to the lower Silurian (lowermost Sheinwoodian).

\section{The Grötlingbo-1 core section}

The Grötlingbo-1 core section (67 mm in diameter) originates from a well drilled in 1968 by the Geological Survey of Sweden (SGU) near Grötlingbo village in SE Gotland (Fig. 1). The entire Palaeozoic succession was penetrated. Snäll (1977) published a brief general description of the section (including the interval discussed in this paper); updated lithological logs of the interval studied by us are presented below. Palaeogeographically, the section was located in the same facies belt as the Ohesaare core section in SW Saaremaa, Estonia (in the Late Ordovician, in the transitional belt between the North Estonian and Central Baltoscandian Confacies belts sensu Jaanusson 1976).

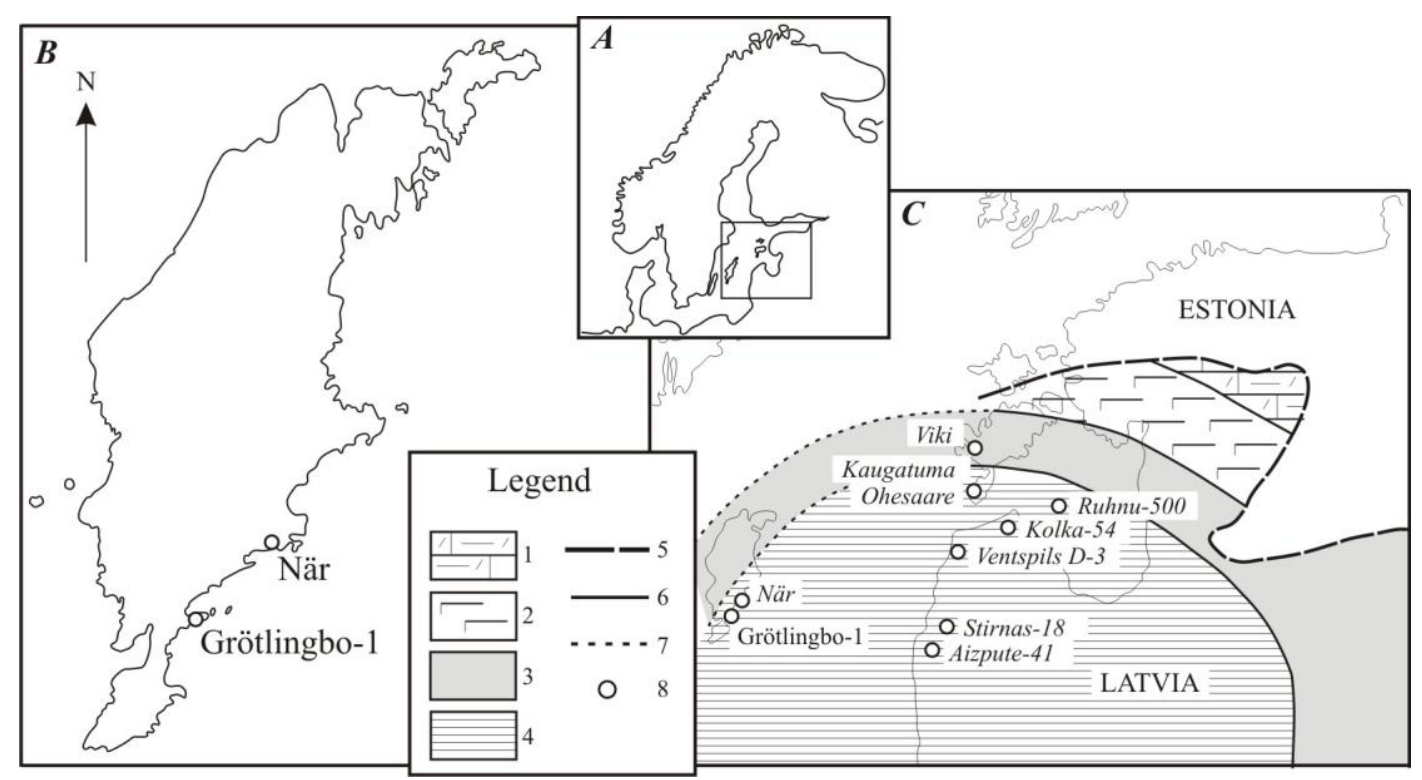

\section{Figure 1}

Location of core sections discussed in the text. Simplified distribution of main facies belts in Telychian is modified from Kaljo \& Jürgenson (1970) and Jeppsson \& Männik (1993). Legend: 1 - shallow shelf (argillaceous bioclastic limestone); 2 - open (deep) shelf (marlstone with interbeds of argillaceous limestone); 3 - transitional belt (argillaceous marlstone, often red-coloured); depression (dark-coloured claystones and silty claystone, graptolites common); 5 - northern and eastern boundary of present distribution of sediments; 6 - boundaries between facies belts; 7 - probable boundaries between facies belts; 8 - borehole.

The Upper Ordovician interval in the section consists mainly of various limestones: of pure mudstone and wackestone with pyritized bioclastic material in its lower part (interval 420.3-435.0+ $\mathrm{m}$ ) and of more argillaceous varieties of these rocks in the upper part (Fig. 2). In the upper part of the section, two intervals (405.1-415.4 $\mathrm{m}$ and 418.3-419.0 m) of red strata occur. Several intervals in the succession are represented by calcareous and/or argillaceous marlstone. Discontinuity surfaces are numerous in the interval 420.3-424.8 m; glauconite is common in $420.3-421.7 \mathrm{~m}$. At $398.5 \mathrm{~m}$ is a thin interbed of intraformational conglomerate yielding ooids. Argillaceous marlstone just below this interbed is rich in small brachiopods. 


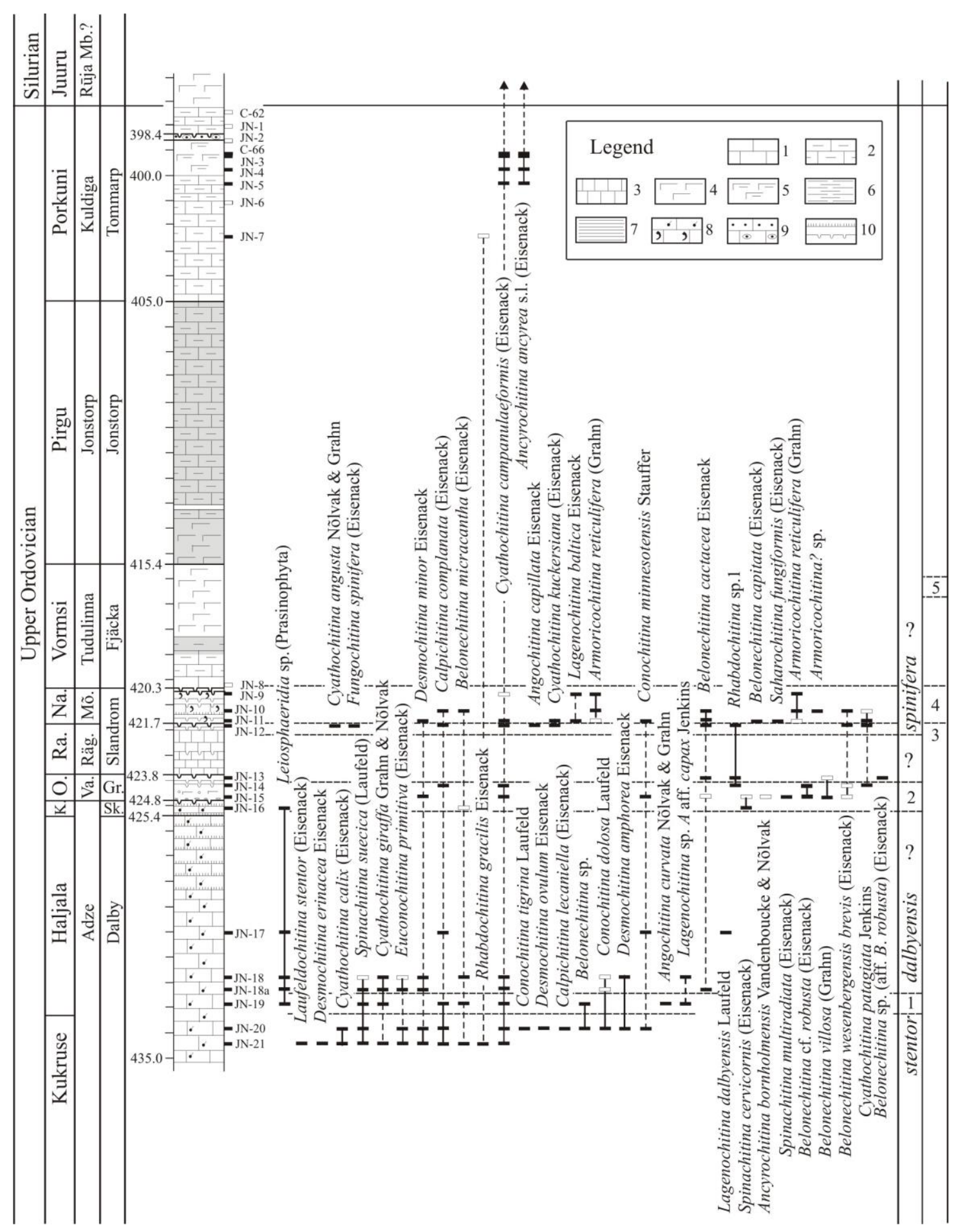

\section{Figure 2}

Distribution of Ordovician chitinozoans. From left to right: Series/System; Regional Stage in East Baltic; lithological log; samples and their numbers (white boxes - barren samples); distribution of taxa (black boxes - reliable identifications, white boxes - problematical identifications); chitinozoan zones; chitinozoan subzones. Ranges of taxa: solid line continuous occurrence of a taxon; dotted line - sporadic occurrence of a taxon. Arrow at the end of a distribution line indicates that the taxon occurs also higher in the section. With numbers are indicated: 1 - Belonechitina postrobusta $\mathrm{CtZ}$; 2 - Spinachitina cervicornis CtZ; 3 - Cyathochitina angusta Chitinozoan Subzone (CtSZ); 4 - Armoricochitina reticulifera $\mathrm{CtSZ} ; 5$ - Acanthochitina barbata $\mathrm{CtSZ}$ (based on data from Grahn \& Nõlvak 2010). Abbreviations: K. Keila Stage; O. - Oandu Stage; Ra. - Rakvere Stage; Na. - Nabala Stage; Va. - Variku Formation; Räg. - Rägavere Formation; Mõ. - Mõntu Formation; Sk. - Skagen; Gr. - Gräsgård Siltstone. Legend: 1 - limestone; 2 - argillaceous limestone; 3 - cryptocrystalline limestone; 4 - calcareous marlstone; 5 - argillaceous marlstone; 6 - claystone; 7 - silty claystone; 8 - pyritized bioclast (above) and glauconite grains (below); 9 - lithoclasts (above) and ooids (below); 10 - Kbentonite (above) and discontinuity surface (below). 
The rocks of Llandovery age in the section are dominated by more or less calcareous marlstone (mudstone) ranging from light and dark grey to bluish and greenish grey (Fig. 3). Some intervals are strongly bioturbated. Several thin interbeds of light coloured argillaceous limestone with rare fine bioclastic material occur. The lowermost part of the Silurian succession (interval 386.6-397.1 m) is dominated by argillaceous limestone (mudstone and wackestone) with a red-coloured interval in the middle part of it. The uppermost part of the interval studied by us (above $345.8 \mathrm{~m}$ ) consists mostly of dark-coloured, often microlaminated, graptolitic claystone and silty claystone.

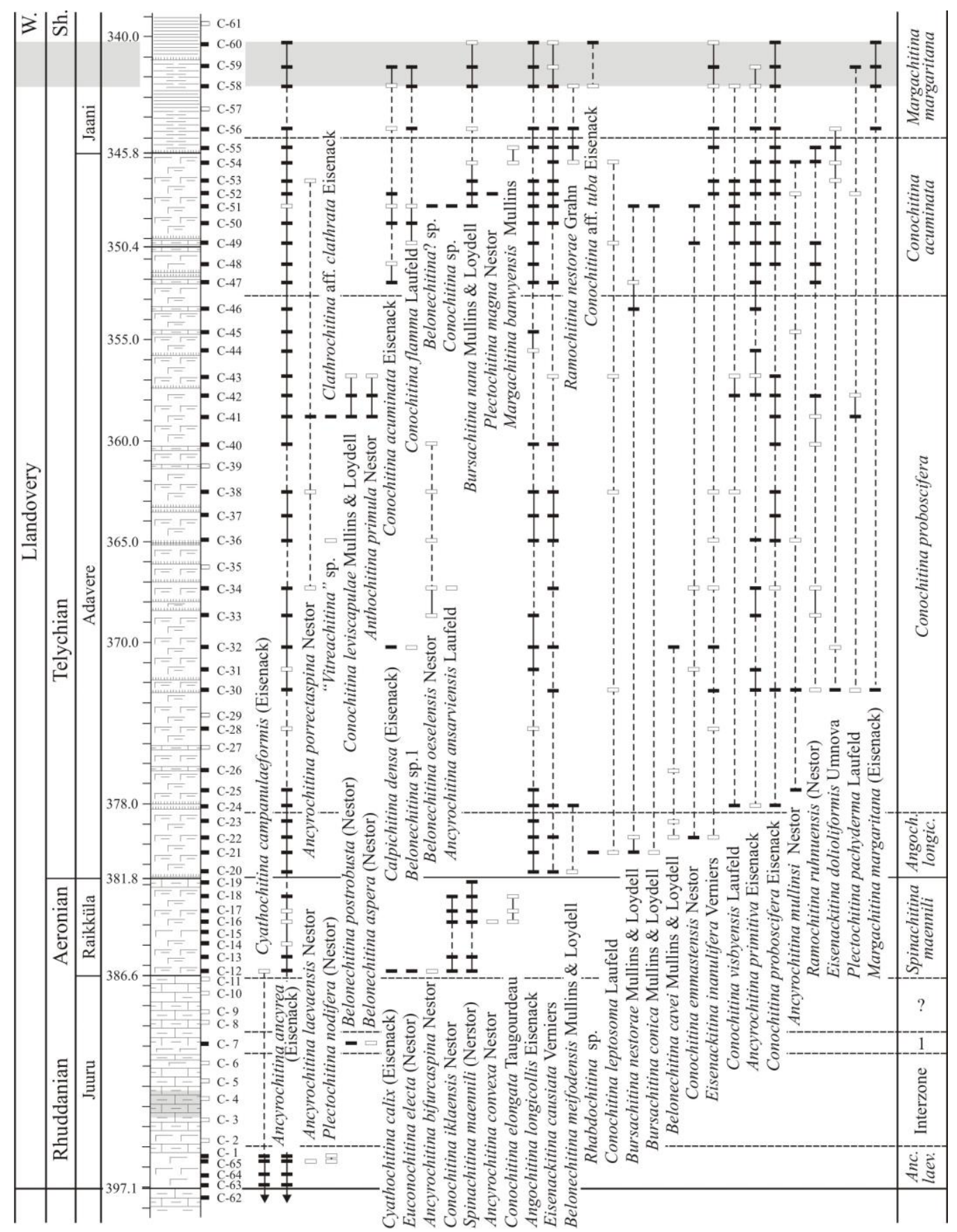

\section{Figure 3}

Distribution of Silurian chitinozoans. From left to right: Series; Regional Stage in East Baltic; lithological log; samples and their numbers (white boxes - barren samples); distribution of taxa (black boxes - reliable identifications, white boxes - problematical identifications); chtinozoan zones. Ranges of taxa: solid line - continuous occurrence of a taxon; dotted line - sporadic occurrence of a taxon. Arrow at the end of a distribution line indicates that the taxon occurs also below the interval. With numbers are indicated: 1 - Angochitina curvata CtZ; 2 - Margachitina banwyensis CtZ. Abbreviations: W.

- Wenlock; Cyathochit. - Cyathochitina; Belonechit. - Belonechitina; Ancyrochit. - Ancyrochitina; Anc. laev. Ancyrochitina laevaensis; Angoch. longic. - Angochitina longicollis. For legend refer to Fig. 2. 


\section{Material and methods}

The Upper Ordovician (Sandbian to Hirnantian) and lower Silurian (Rhuddanian to lowermost Sheinwoodian) parts of the core were sampled for biostratigraphical studies by J. Nõlvak and P. Männik in 1993 (with the help of Prof. Maurits Lindström and Dr Stefan Hagenfeldt). The Upper Ordovician interval was sampled unevenly because, originally, the samples were intended for chitinozoan studies only. As it is known that red-coloured rocks do not yield these fossils, the intervals represented by such rocks were not sampled. The uppermost Upper Ordovician and the lower Silurian were sampled more regularly.

All samples were processed in buffered acetic acid. This worked well with samples containing sufficient calcareous material (limestone and calcareous marlstone, mainly samples coming from the strata below $386 \mathrm{~m}$ in the section). Most of the samples above this level did not disintegrate in the acetic acid and several other methods (processing in formic acid, immersing a sample in hot water after soaking it in petrol, boiling a sample in soda, etc.) were applied. Still, for many samples, only a small part of them disintegrated. Hence, in many cases low numbers of chitinozoans and conodonts in a sample do not indicate true rare occurrences in the rock but result from processing problems. In total, 88 samples with weights varying between $0.25 \mathrm{~kg}$ and $0.50 \mathrm{~kg}$ were processed for microfauna. All fossils (conodonts, chitinozoans and graptolites) were picked from the same residues. Additionally, 12 rock slabs bearing graptolites from the Silurian part of the section were studied (Fig. 4), mostly material originally destined for processing for conodonts. All but three samples (JN-12, JN-13 and JN-15) from the Ordovician part of the section yielded conodonts. The residues of two Silurian samples (C-27 and C-46) were lost before the picking of conodonts. Chitinozoans were found in 19 samples from the Ordovician part of the section and from 49 samples from its Silurian part (Figs 2, 3). Fragments of graptolites were found in 22 of the processed samples but unfortunately this material contained no determinable biostratigraphically useful specimens. All biostratigraphical samples studied are housed in the Institute of Geology at Tallinn University of Technology (collection 688); the core is stored in SGU (Uppsala, Sweden). 


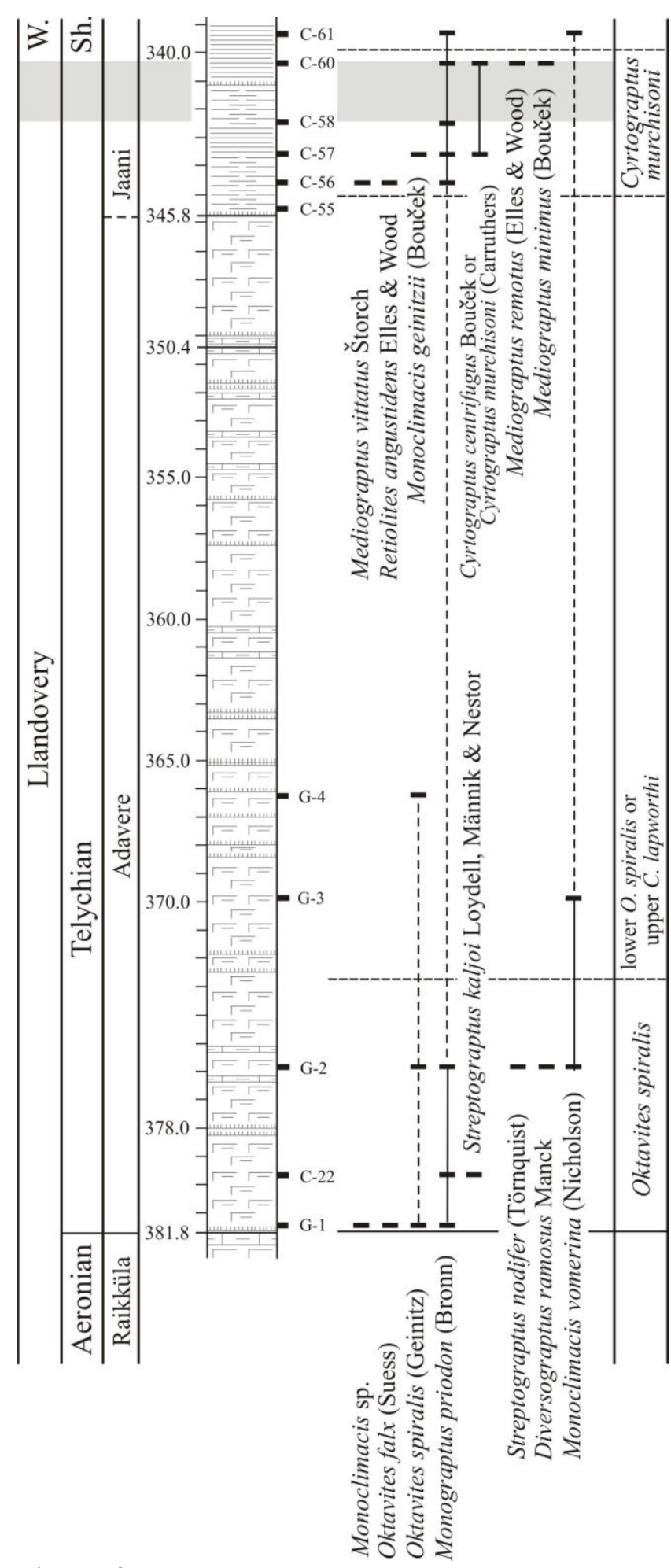

\section{Figure 4}

Distribution of Silurian graptolites in the samples available from the Grötlingbo-1 core section.

\section{Distribution of chitinozoans}

\section{Ordovician}

The stratigraphical distribution of the Ordovician chitinozoans was described by Grahn (1982) and later revised in Grahn \& Nõlvak (2010); new finds are shown in Fig. 2; selected taxa are illustrated in Fig. 5. For ease of comparison with earlier publications, and with East Baltic successions, two different schemes for lithological units are indicated in the left-hand column in Fig. 2: the traditional Swedish topoformations (Jaanusson 1976; Ebbestad \& Högström 2007, fig. 3) and the standard regional units used in the East Baltic (Männil 1990;

Nõlvak 1997, tab. 7). 


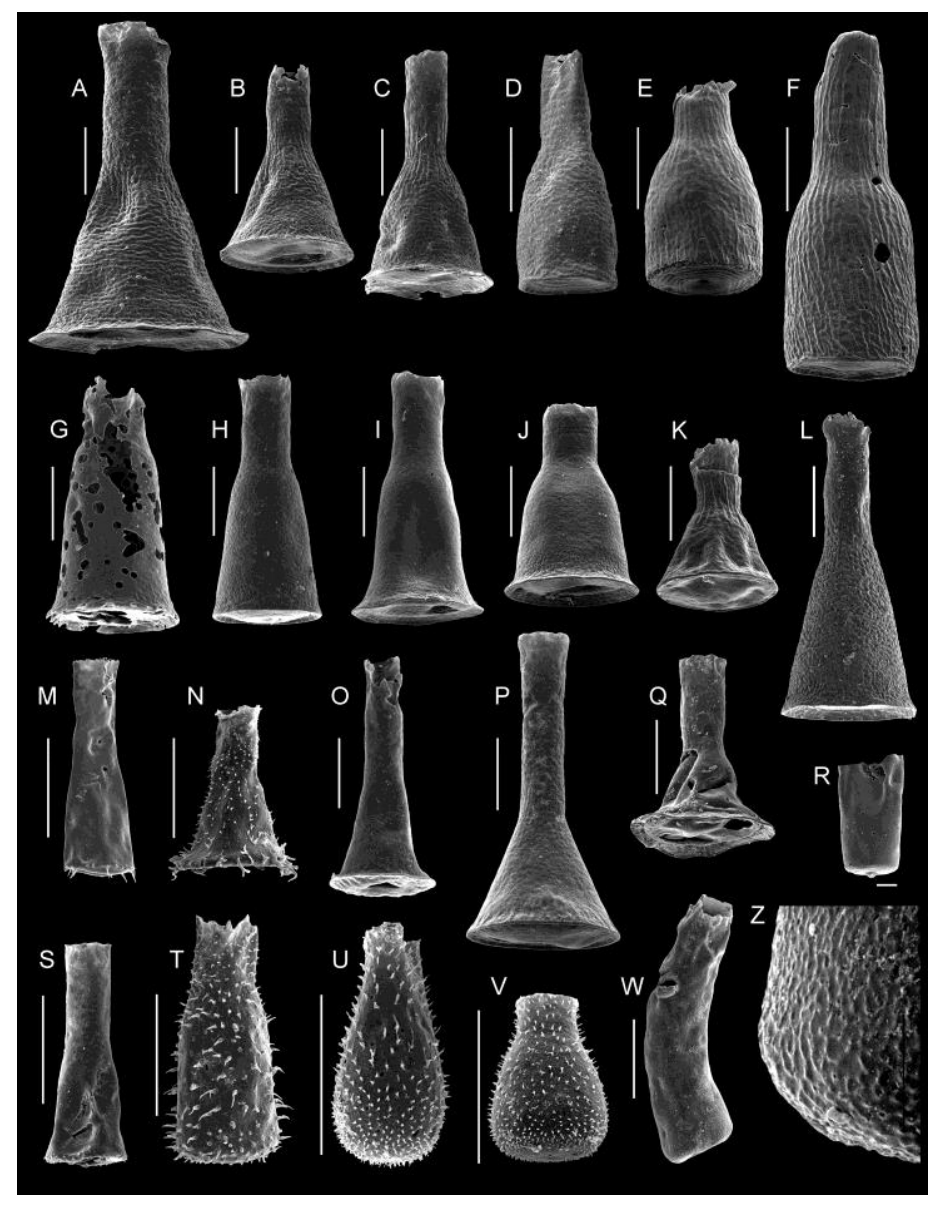

\section{Figure 5}

Selected Ordovician chitinozoans from the Grötlingbo-1 core section. Scale bar represents $100 \mu \mathrm{m}$, except for $\mathbf{R}$ and $\mathbf{Z}$ $20 \mu \mathrm{m}$. A. Cyathochitina campanulaeformis (Eisenack), GIT 688-1, ( L: $445 \mu \mathrm{m}$ ), sample JN-11. B. Cyathochitina campanulaeformis, GIT 688-2, (L: $285 \mu \mathrm{m}$ ), sample JN-11. C. Cyathochitina cf. patagiata Jenkins, GIT 688-3, sample JN-11. D. Armoricochitina cf. reticulifera (Grahn), GIT 688-4, (L: $281 \mu \mathrm{m}$ ), sample JN-11. E. Armoricochitina reticulifera, GIT 688-5, sample JN-10. F. Armoricochitina? sp., GIT 688-6, (L: $406 \mu \mathrm{m}$ ), sample JN-10. G. Cyathochitina angusta Nõlvak \& Grahn, GIT 688-7, secondary perforation made by parasite activity, sample JN-12. H. Cyathochitina cf. angusta, GIT 688-8, sample JN-12. I. Cyathochitina cf. angusta, GIT 688-9, sample JN-12. J. Cyathochitina patagiata Jenkins, GIT 688-10, sample JN-12. K. Cyathochitina campanulaeformis, GIT 688-11, sample JN-12. L. Cyathochitina cf. campanulaeformis, GIT 688-12, sample JN-11. M. Spinachitina multiradiata (Eisenack), GIT 688-13, sample JN-15. N. Spinachitina cervicornis (Eisenack), GIT 688-14, sample JN-15. O. Cyathochitina cf. giraffa (Grahn \& Nõlvak), GIT 68815, sample JN-19. P. Cyathochitina giraffa, GIT 688-16, (L: 424), sample JN-19. Q. Cyathochitina kuckersiana (Eisenack 1934), GIT 688-17, sample JN-11. R. Rhabdochitina sp.1(broken), GIT 688-18, sample JN-12. S. Belonechitina micracantha (Eisenack), GIT 688-19, sample JN-19. T. Belonechitina villosa (Grahn), GIT 688-20, sample JN-15. U. Angochitina capillata Eisenack, GIT 688-21, sample JN-12. V. Belonechitina cactacea (Eisenack), GIT 688-22, sample JN-12. W-Z. Belonechitina sp. aff. robusta (Eisenack), GIT 688-23, sample JN-15.

The lowermost sample studied (JN-21: 434.40-434.45 m) yielded Laufeldochitina stentor suggesting that the sample comes from the Lauf. stentor Chitinozoan Zone (CtZ) sensu Nõlvak \& Grahn (1993). Angochitina curvata occurs only in sample JN-19 (432.90-432.95 m) indicating that the Ang. curvata CtZ is very thin in the section. The strata above are considered to correspond to the Lagenochitina dalbyensis $\mathrm{CtZ}$ although Lag. dalbyensis itself appears higher in the section and was found in sample JN-17 (430.05-430.10 m) only. Above this sample an interval about $6 \mathrm{~m}$ thick was not sampled.

The next set of samples from the interval 424.12-425.15 m (JN-14 to JN-16) yielded rich faunas characteristic of the Spinachitina cervicornis $\mathrm{CtZ}$. The upper boundary of the $S$. cervicornis $\mathrm{CtZ}$ is marked by the disappearance of S. cervicornis and Ancyrochitina bornholmensis (Nõlvak et al. 2006). The age of sample JN- 
13 is problematical. Chitinozoans are rare in this sample, most probably due to the small size of it. The appearance of Fungochitina spinifera in sample JN-12 (421.87-421.93 m) and the occurrence of Armoricochitina reticulifera (Fig. 5: D, E) higher in the section, in the interval 420.45-421.65 m (samples JN-9 to JN-11), correlates this interval with the Fung. spinifera CtZ. The uppermost sample in this set, JN-8 (420.15-420.20 m), comes from a limestone with red spots and did not yield chitinozoans.

Above sample JN-8, an interval almost $18 \mathrm{~m}$ thick, consisting mainly of red-coloured rocks, was not sampled. The samples above the unsampled strata (samples C-62, C-66, JN-1 to JN-7 from interval 397.60-402.55 m) were either barren or yielded long-ranging, stratigraphically undiagnostic taxa.

\section{Silurian}

50 species of chitinozoans have been identified in the studied Silurian part of the Grötlingbo- 1 core section (Figs 3, 6). The lowermost Silurian sample (C-62: 397.50-397.60 m) was barren. The next two samples (C-63 and C-64 from the interval 396.35-396.92 m) yielded only the long-ranging taxa Cyathochitina campanulaeformis (Fig. 6: A) and Ancyrochitina ancyrea which are known to occur also in the Upper Ordovician. The next samples (C-1 and C-65) from the interval 395.43-395.85 m contained Anc. cf. laevaensis and Plectochitina nodifera, indicating the basal Silurian Anc. laevaensis CtZ for this interval (Nestor 1994, 2012). 


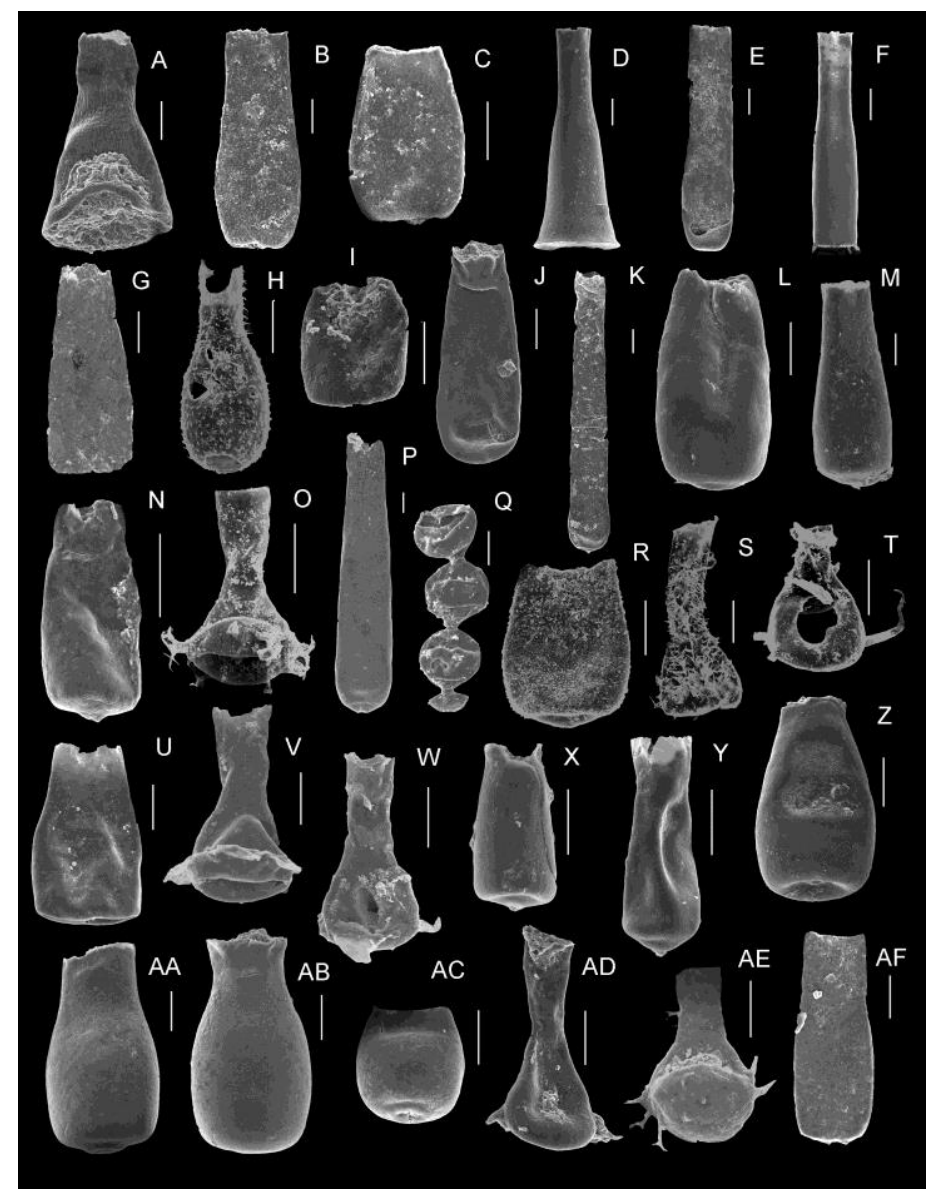

\section{Figure 6}

Selected Silurian chitinozoans from the Grötlingbo-1 core section. Scale bar represents $50 \mu \mathrm{m}$. A. Cyathochitina campanulaeformis (Eisenack), GIT 688-24, sample C-65, 395.75-395.85 m. B. Belonechitina postrobusta (Nestor), GIT 688-25, sample C-7, 389.88-390 m. C. Belonechitina aspera (Nestor). GIT 688-26, sample C-7, 389.88-390 m. D.

Cyathochitina calix (Eisenack). GIT 688-27, sample C-12, 386.17-386.25 m. E. Conochitina iklaensis Nestor. GIT 68828, sample C-12, 386.17-386.25 m. F. Spinachitina maennili Nestor. GIT 688-29, sample C-12, 386.17-386.25 m. G. Conochitina elongata Taugourdeau. GIT 688-30, sample C-16, 382.65-382.75 m. H. Angochitina longicollis Eisenack. GIT 688-31, sample C-21, 380.35-380.45 m. I. Eisenackitina causiata Verniers. GIT 688-32, sample C-22,

379.60-379.70 m. J. Conochitina praeproboscifera Nestor. GIT 688-33, sample C-21, 380.35-380.45 m. K. Conochitina leptosoma Laufeld. GIT 688-34, sample C-30, 372.40-372.50 m. L. Bursachitina nestorae Mullins \& Loydell. GIT 68835, sample C-51, 348.38-348.48 m. M. Conochitina emmastensis Nestor. GIT 688-36, sample C-22, 379.60-379.70 m. N. Conochitina visbyensis Laufeld. GIT 688-37, sample C-24, 378.36-378.48 m. O. Ancyrochitina mullinsi Nestor. GIT 68838, sample C-25, 377.28-377.37 m. P. Conochitina proboscifera Eisenack. GIT-39, sample C-30, 372.40-372.50 m. Q. Margachitina margaritana (Eisenack). GIT 688-40, sample C-30, 372.40-372.50 m. R. Eisenackitina dolioliformis Umnova. GIT 688-41, sample C-30, 372.40-372.50 m. S. Ramochitina ruhnuensis Nestor. GIT 688-42, sample C-42, 357.75-357.85 m. T. Ancyrochitina porrectaspina Nestor. GIT 688-43, sample C-34, 367.25-367.38 m. U. Conochitina leviscapulae Mullins \& Loydell. GIT 688-44, sample C-41, 358.80-358.90 m. V. Anthochitina primula Nestor. GIT 68845, sample C-41, 358.80-358.90 m. W. Plectochitina pachyderma (Laufeld). GIT 688-46, sample C-41, 358.80-358.90 m. X. Conochitina acuminata Eisenack. GIT 688-47, sample C-50, 349.16-348.28 m. Y. Conochitina flamma Laufeld. GIT 688-48, sample C-50, 349.16-349.28 m. Z. Bursachitina conica (Taugourdeau \& de Jekhowsky). GIT 688-49, sample C51, 348.38-348.48 m. AA. Conochitina sp. GIT 688-50, sample C-51, 348.38-348.48 m. AB. Belonechitina? sp. GIT 68851, sample C-51, 348.38-348.48 m. AC. Bursachitina cf. nana (Nestor). GIT 688-52, sample C-52, 347.65-347.77 m. AD. Plectochitina magna Nestor. GIT 688-53, sample C-52, 347.65-347.77 m. AE. Ramochitina nestorae Grahn. GIT 688-54, sample C-55, 345.45-345.53 m. AF. Conochitina aff. tuba Eisenack. GIT 688-55, sample C-60, 340.23-340.35 m.

Five samples from the interval $390.85-394.81 \mathrm{~m}$ (C-2 to C-6) were barren and the interval is here dealt with as an Interzone. Barren beds in the same stratigraphical interval have been recognised also in the Ventspils D-3, Ohesaare, Ruhnu-500, Aizpute-41 and Kolka-54 core sections (Nestor 1994; Loydell, Männik \& Nestor 2003; Loydell, Nestor \& Männik 2010). In sample C-7 (at 389.88-389.90 m), above the barren interval,

Belonechitina postrobusta (Fig. 6: B), a species characteristic of the Bel. postrobusta CtZ, has been found. 
Four samples from higher in the section (C-8 to C-11, from the interval 387.32-388.95 m), between the level of occurrence of Bel. postrobusta and that of the appearance of Spinachitina maennili (Fig. 6: F) in sample C-12 (386.17-386.25 m), were barren. The interval with Spin. maennili corresponds to the Spin. maennili CtZ. The only specimen of Euconochitina electa in the studied section comes from the lowermost part of this zone (sample C-12). It is quite probable that the Euc. electa $\mathrm{CtZ}$ corresponds to (part of) the barren interval below the level of appearance of Spin. maennili. Conochitina iklaensis (Fig. 6: E) occurs together with Spin. maennili throughout most of the Spin. maennili CtZ, whilst rare specimens of Cyath. calix (Fig. 6: D) and Anc. cf. bifurcaspina occur only in the lowermost sample in the zone, and Anc. cf. convexa and Con. elongata (Fig. 6: G) occur only in the upper part of the zone.

The assemblage of chitinozoans occurring in the strata above, in the interval 378.80-381.32 m (samples C-20 to C-23), includes Angochitina longicollis (Fig. 6: H), Eisenackitina causiata (Fig. 6: I), Con. praeproboscifera (Fig. 6: J), Con. emmastensis (Fig. 6: M), Bursachitina nestorae (Fig. 6: L), Bel. cf. cavei and some others. These taxa are characteristic of the Ang. longicollis $\mathrm{CtZ}$ and suggest a late mid Telychian age for these strata.

The upper Telychian chitinozoan biozones are well represented in the Grötlingbo-1 core section. The Con. proboscifera $\mathrm{CtZ}$ is about $25 \mathrm{~m}$ thick (corresponding to the interval $353.43-378.48 \mathrm{~m}$ : samples C-24 to C-46) in the section. Together with the zonal species, Ang. longicollis and Eis. causiata are most characteristic of the zone. Eis. inanulifera, Eis. dolioliformis (Fig. 6: R), Ramochitina ruhnuensis (Fig. 6: S) and Con. visbyensis (Fig. 6: N) appear in the lower part and Anc. porrectaspina (Fig. 6: T) and Con. leviscapulae (Fig. 6: U) in the upper part of the zone. In sample C-30 (372.40-372.50 m) Margachitina margaritana (Fig. 6: Q) has been found. Such an early appearance of this species, in the Oktavites spiralis Graptolite Zone (GZ), was established also in the Ventspils core section (Loydell \& Nestor 2005) and was reported also by Grahn (1995) from the När core, Gotland. In the interval 356.80-358.90 m Anthochitina primula (Fig. 6: V) was found, a species which occurs usually in the lowermost part of the next, Con. acuminata CtZ (in the Viki, Kolka-54 and Ruhnu-500 cores: Nestor 1994; Loydell, Nestor \& Männik 2010).

Con. acuminata (Fig. 6: X) appears in sample C-47 (352.02-352.12 m) indicating that the lower boundary of the Con. acuminata $\mathrm{CtZ}$ lies below this level. In addition to the zonal species, Con. flamma (Fig. 6: Y), Burs. nana (Fig. 6: AC) and Plect. magna (Fig. 6: AD) (in ascending order of appearances) as well as some other less common species appear in this zone.

The Marg. banwyensis $\mathrm{CtZ}$ has been distinguished in the interval 345.45-346.23 m. Together with the zonal taxon some transitional species occur and Ram. nestorae (Fig. 6: AE) appears in this zone.

The reappearance of Marg. margaritana in sample C-56 (344.55-344.64 m) indicates the lower boundary of the Marg. margaritana CtZ. Con. aff. tuba (Fig. 6: AF) is the only new species that appears in this zone, in the uppermost part of the studied interval in the Grötlingbo-1 core section. 


\section{Distribution of conodonts}

\section{Ordovician}

The lowermost six samples studied (JN-17 to JN-21) come from the interval 430.05-434.45 m (Fig. 7).

Conodonts in these samples indicate that it corresponds to the Baltoniodus gerdae Conodont Zone (CZ) in the middle part of the Amorphognathus tvaerensis Conodont Superzone (CSZ).

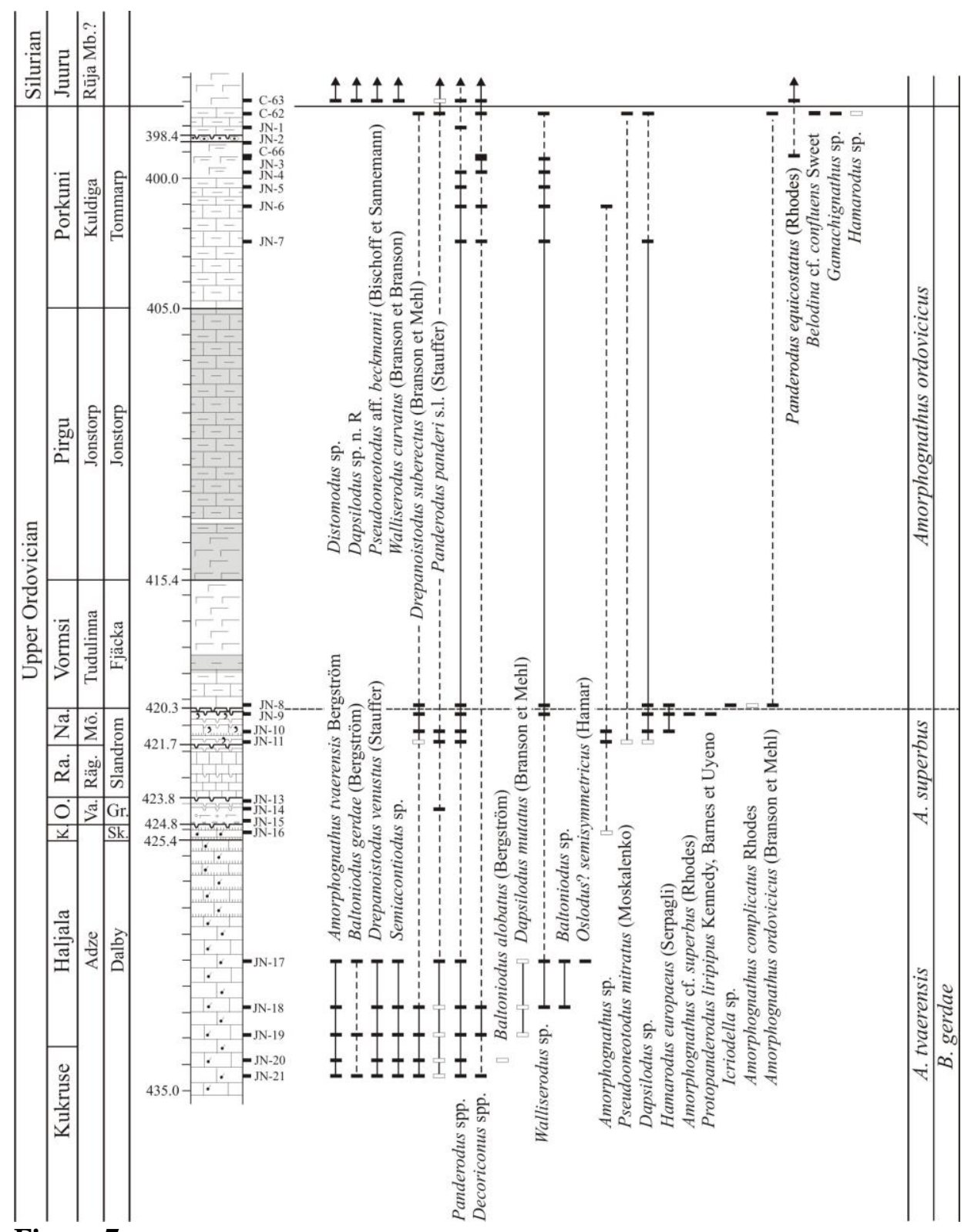

\section{Figure 7}

Distribution of Ordovician conodonts in the Grötlingbo-1 core section. For explanation and legend refer to Fig. 2. Abbreviations: A. - Amorphognathus; B. - Baltoniodus.

The samples from the interval $423.95-425.15 \mathrm{~m}$ (JN-13 to JN-16) yielded extremely poor faunas and no stratigraphically diagnostic taxa were found. Only two of the four samples from this interval yielded conodonts: from sample JN-16 (425.10-425.15 m) a fragment of Amorphognathus sp. and from sample JN-14 (424.12$424.17 \mathrm{~m})$ a single specimen of Panderodus panderi.

A relatively rich fauna appears in sample JN-11 (421.60-421.65 m), in the lowermost sample in the next set of four samples in the interval 420.15-421.65 m (JN-8 to JN-11). At this level Amorphognathus sp., Dapsilodus sp. (both too poorly preserved to allow species identification) and Pseudooneotodus cf. mitratus, and somewhat 
higher Hamarodus europaeus (Fig. 8: D) appear. The occurrence of Am. cf. superbus (Fig. 8: G) in sample JN9 (420.45-420.50 m) indicates that this level corresponds to the Am. superbus CZ. However, the occurrence of Hamarodus europaeus (not known from strata below the Am. superbus CZ; Männik 2003; Männik \& Viira 2005) in sample JN-10 (421.30-421.35 m) suggests that this sample also comes from the Am. superbus CZ. The uppermost sample in this interval, JN-8 (420.15-420.20 m), yielded Am. ordovicicus and fragments of Icriodella sp. indicating that the boundary between the Am. superbus $\mathrm{CZ}$ and Am. ordovicicus $\mathrm{CZ}$ is in the interval $420.20-420.45 \mathrm{~m}$.

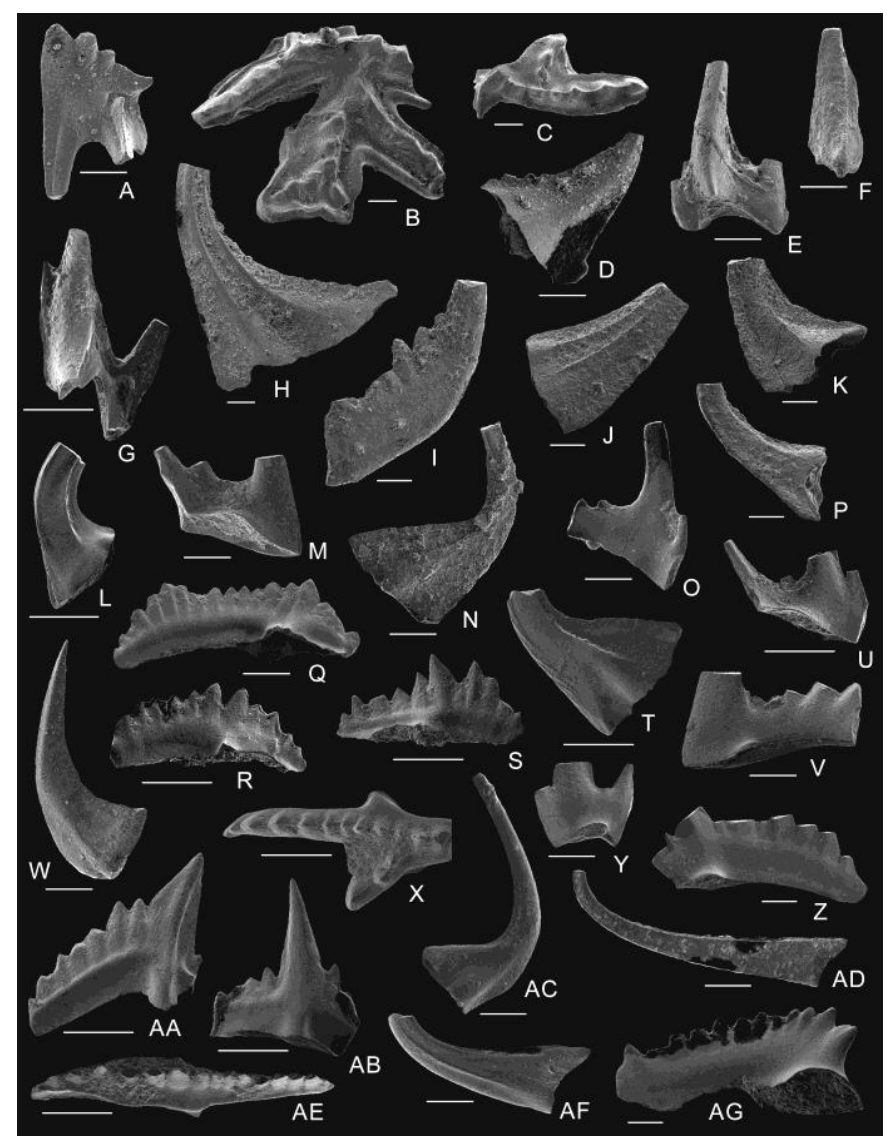

\section{Figure 8}

Selected conodonts from the Grötlingbo-1 core section. Scale bar represents $100 \mu \mathrm{m}$.

A, B. Amorphognathus tvaerensis Bergström. A - M element, GIT 688-56; B - Pa element, GIT 688-57. Both specimens from sample JN-21, 434.40-434.45 m. C. Baltoniodus gerdae (Bergström). Pa element, GIT 688-58, sample JN-21, 434.40-434.45 m. D. Hamarodus europaeus (Serpagli). Pb(?) element, GIT 688-59, sample JN-9, 420.45-420.50 m. E, F. Amorphognathus ordovicicus (Branson \& Mehl). M elements, GIT 688-60 and GIT 688-61, sample C-62, 397.50-397.60 m. G. Amorphognathus cf. superbus Rhodes. M element, GIT 688-62, sample JN-9, 420.45-420.50 m. H. Protopanderodus liripipus Kennedy, Barnes \& Uyeno. GIT 688-63, sample JN-9, 420.45-420.50 m. I. Belodina cf. confluens Sweet. GIT 688-64, sample C-62, 397.50-397.60 m. J, K, P. Walliserodus curvatus (Branson \& Branson). J multicostatiform element, GIT 688-65; K - curvatiform element, GIT 688-66; P - deboltiform element, GIT 688-67. All specimens from sample C-4, 392.55-392.65 m. L. Dapsilodus praecipuus Barrick. GIT 688-68, sample C-21, 380.35380.45 m. M, O, U. Aspelundia? expansa Armstrong. M - M element, GIT 688-69; O - Sc element, GIT 688-70; U $\mathrm{Pb}$ (?) element, GIT 688-71. All specimens from sample C-13, 385.59-385.69 m. N. Dapsilodus sp. n. R. GIT 688-72, sample C-4, 392.55-392.65 m. Q. Pterospathodus amorphognathoides angulatus (Walliser). Pa element, GIT 688-73, sample C-20, 381.22-381.32 m. R, S. Pterospathodus celloni (Walliser). Pa elements, GIT 688-74 and GIT 688-75, sample C-20, 381.22-381.32 m. T. Dapsilodus obliquicostatus (Branson \& Mehl). GIT 688-76, sample C-61, 339.35$339.45 \mathrm{~m}$. V, Y. Aspelundia? fluegeli (Walliser). V - M element, GIT 688-77; Y - Pa(?) element, GIT 688-78. Bothy specimens from sample C-21, 380.35-380.45 m. W. Panderodus n. sp. N Jeppsson \& Männik. Falciform element, GIT 688-79, sample C-29, 373.56-373.68 m. X, AB. Pterospathodus pennatus procerus (Walliser). X - Pa element, GIT 68880; $\mathrm{AB}-\mathrm{Pb}_{1}$ element, GIT 688-81. Both specimens from sample C-43, 356.80-356.90 m. Z. Wurmiella excavata (Branson \& Mehl). Pa element, GIT 688-82, sample C-61, 339.35-339.45 m. AA, AE. Pterospathodus amorphognathoides amorphognathoides Walliser. AA - $\mathrm{Pb}_{1}$ element, GIT 688-83; AE - Pa element, GIT 688-84. Both specimens from sample C-43, 356.80-356.90 m. AC, AD, AF. Panderodus langkawiensis Igo \& Koike. AC - falciform element, GIT 688-85; AD - graciliform element, GIT 688-86; AF - graciliform(?) element, GIT 688-87. All specimens from sample C-43, 356.80356.90 m. AG. Kockelella ranuliformis (Walliser). Pa element, GIT 688-88, sample C-43, 356.80-356.90 m. 
An interval more than $17 \mathrm{~m}$ thick in the section is dominated by red-coloured limestone and was not sampled. Starting from sample JN-7 (402.50-402.55 m) up to the top of the studied interval the section was sampled regularly, with the intervals between samples, as a rule, less than $1 \mathrm{~m}$. The samples in the interval 399.15402.55 m (JN-7 to C-66) yielded mainly poorly preserved specimens of Decoriconus, Panderodus and Walliserodus. Species are not identifiable.

The uppermost Am. ordovicicus (Fig. 8: E, F) and Hamarodus sp. in the section were found in sample C-62 (397.50-397.60 m), from the uppermost part of the limestone in the interval 397.05-398.45 m. Belodina cf. confluens (Fig. 8: I) and Gamachignathus sp. occur in this sample. The occurrence of Am. ordovicicus in this sample indicates that this level corresponds still to the Am. ordovicicus CZ.

\section{Silurian}

Rich faunas strongly dominated by Pand. equicostatus appear in sample C-63 (396.92-396.99 m), in the lowermost part of green to greenish grey calcareous marlstone, rich in fine to coarse bioclastic material (Fig. 9). In the same sample Walliserodus curvatus (Fig. 8: J, K, P), Dapsilodus sp. n. R (Fig. 8: N) and Distomodus sp. appear. Such faunas, without major changes in composition and still dominated by Pand. equicostatus, continue up to sample C-13 (385.59-385.69 m). Aspelundia? expansa (Fig. 8: M, O, U) appears in this sample, indicating that the boundary between the D. kentuckyensis $\mathrm{CZ}$ and Asp.? expansa $\mathrm{CZ}$ lies below it. The upper boundary of the Asp.? expansa CZ, marked by a distinct change in the conodont assemblage (below), lies above sample C-19 (381.87-382.00 m). In Fig. 9 the boundary is tentatively drawn as corresponding to the level of lithological change at $381.85 \mathrm{~m}$. In sample C-19 the stratigraphically highest specimens of most taxa (including Asp.? expansa, Dapsilodus sp. n. R, Wall. curvatus) characteristic of the lowermost Silurian in the section occur. 


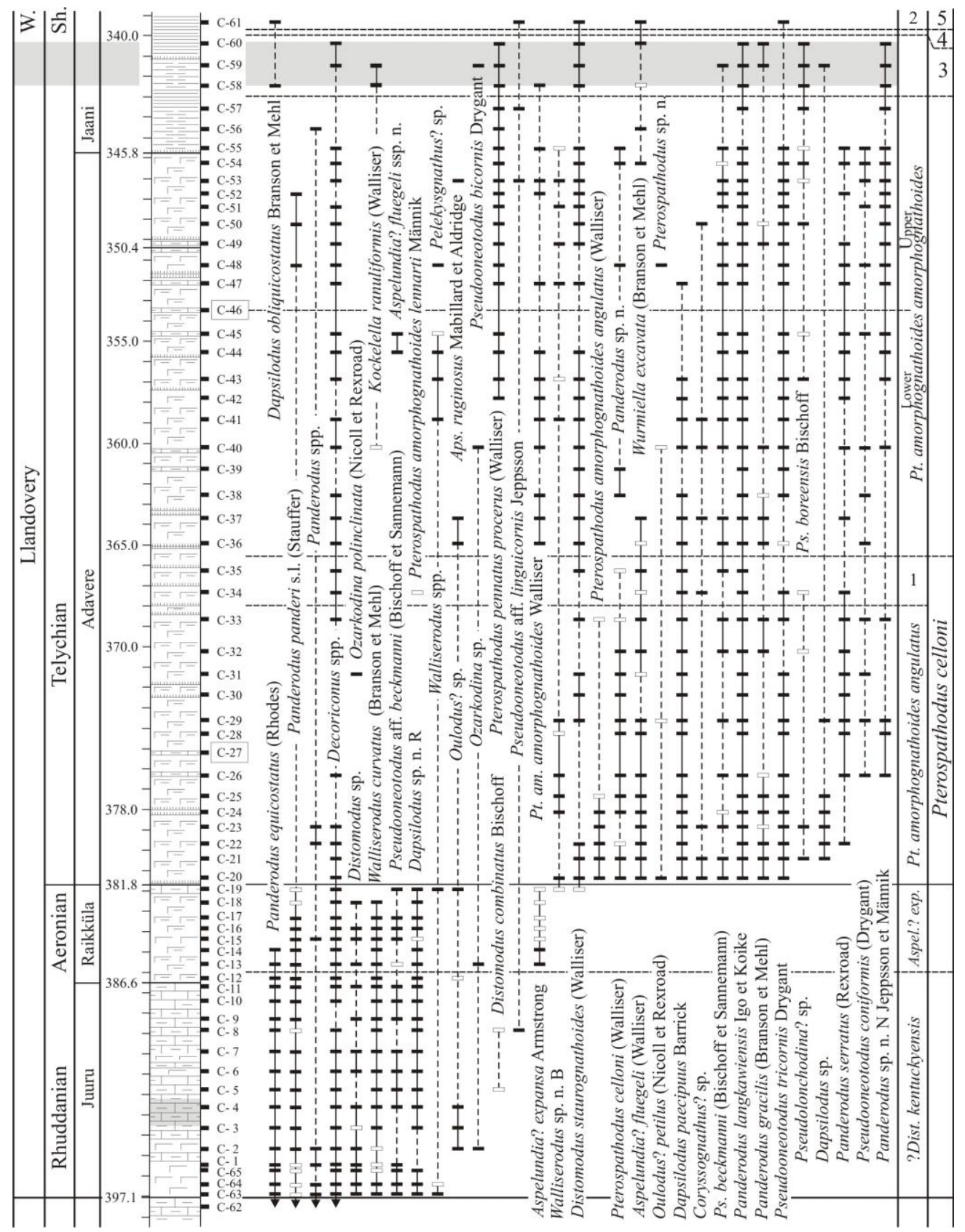

\section{Figure 9}

Distribution of Silurian conodonts. For main explanations refer to Fig. 3, for legend to Fig. 2. Residues of two samples (numbers in boxes) were lost before picking. Abbreviations: W. - Wenlock; Aps. - Apsidognathus; Pt. - Pterospathodus; am. - amorphognathoides; Ps. - Pseudooneotodus; Dist. - Distomodus; Aspel.? exp. - Aspelundia? expansa. In the right side of the figure are indicated conodont zones followed by conodont superzones. With numbers are indicated: 1 probable interval of the Pterospathodus amorphognathoides lennarti and Pterospathodus amorphognathoides lithuanicus CZ-s; 2 - Lower Kockelella ranuliformis CZ; 3 - Pseudooneotodus bicornis CSZ; 4 - Pterospathodus pennatus procerus CSZ; 5 - Kockelella ranuliformis CSZ.

A very rich and taxonomically variable conodont fauna appears in sample C-20 (381.22-381.32 m). Characteristic of the interval up to sample C-33 (368.58-368.70 m) are Pterospathodus celloni (Fig. 8: R, S), Pt. amorphognathoides angulatus (Fig. 8: Q), Asp.? fluegeli (Fig. 8: V, Y), Daps. praecipuus (Fig. 8: L), Dist. staurognathoides, Pand. langkawiensis (Fig. 8: AC, AD, AF), Ps. tricornis and Walliserodus sp. n. B. The occurrence of Pt. a. angulatus indicates that at least the lower part of this interval corresponds to the Pt. $a$. angulatus CZ (to the lower part of the Pt. celloni CSZ). The upper boundary of the Pt. celloni CSZ lies between samples C-35 (366.19-366.29 m) and C-36 (364.93-365.03 m). The appearance of a probable specimen of Pt. a. lennarti in sample C-34 (367.25-367.35 m), in the upper part of the Pt. celloni CSZ, evidently indicates that the boundary between the Pt. a. angulatus $\mathrm{CZ}$ and Pt. a. lennarti $\mathrm{CZ}$ lies below this sample. The uppermost 
zone of the Pt. celloni CSZ, the Pt. a. lithuanicus CZ, cannot be identified in the Grötlingbo-1 core section, either due to a gap or, most probably, because of the too rare occurrence of Pt. a. lithuanicus in the section. Pt. amorphognathoides, characteristic of proximal environments, is known to become rare in the distal graptolitebearing environments where it is replaced by Pt. celloni (in the Pt. a. angulatus-Pt. a. lithuanicus $\mathrm{CZ}-\mathrm{s}$ interval) and by Pt. pennatus procerus (in the Pt. a. amorphognathoides CZ; Männik 1998). This is evidenced also by the sporadic occurrence of Pt. amorphognathoides in the studied section.

The Pt. a. amorphognathoides CZ corresponds to the interval between sample C-36 (364.93-365.03 m) and at least up to sample C-55 (345.45-345.53 m) inclusive. The position of the upper boundary of the zone (corresponds to Datum 1 of the Ireviken Event; Jeppsson 1997) is problematical, but, based on the almost continuous occurrence of Ps. tricornis up to sample C-55 in the section, it is evident that the boundary lies just above this sample or higher. The reappearance of Kockelella cf. ranuliformis (Fig. 8: AG) in sample C-58 (342.41-342.51 m) probably suggests that the boundary should be looked for below this level (K. ranuliformis becomes common at Datum 1 of the Ireviken Event; Jeppsson 1997), in the interval between samples C-55 and C-58. It is drawn between samples C-57 and C-58 on Fig. 9.

The overlying interval, up to and including sample C-60 (340.23-340.45 m), corresponds to the Ps. bicornis CSZ. As noted above, the lower boundary of this CSZ probably lies between samples C-55 and C-58; its upper boundary is above the sample with the uppermost Panderodus sp. n. N (Jeppsson 1997). Two zones, the Lower and Upper Ps. bicornis CZ-s have been recognised in the Ps. bicornis CSZ. The boundary between these zones corresponds to Datum 2 of the Ireviken Event (Jeppsson 1997). However, due to the rare occurrence (lack) of taxa disappearing at this datum in the distal graptolite-bearing environments, this boundary, as a rule, cannot be located in strata formed in such environments (Männik 2007a). Also in the Grötlingbo-1 core section, based on the data available, this boundary cannot be identified. Together with Panderodus sp. n. N (Fig. 8: W), Pt. pennatus procerus (Fig. 8: $\mathrm{X}, \mathrm{AB}$ ) also disappears indicating that the Pt. p. procerus CSZ either corresponds to a gap in the section or lies in the interval between samples C-61 (339.35-339.45 m) and C-60 (340.23-340.45 $\mathrm{m})$.

The uppermost sample studied in the section, C-61, yields poor conodont faunas represented by Dapsilodus obliquicostatus (Fig. 8: T), Wurmiella excavata (Fig. 8: Z), Ps. beckmanni and Ps. bicornis, taxa characteristic of the lower Wenlock in distal environments (Loydell, Männik \& Nestor 2003). Occurring also in this sample is Distomodus staurognathoides indicating that it comes from the Lower Kockelella ranuliformis CZ.

\section{Distribution of graptolites}

Identifiable graptolites were present only within the Silurian part of the core and here only within the Telychian and Sheinwoodian stages (Figs 4,10). They are preserved either as three-dimensional pyrite internal moulds with original periderm surrounding or more commonly as flattened periderm. 


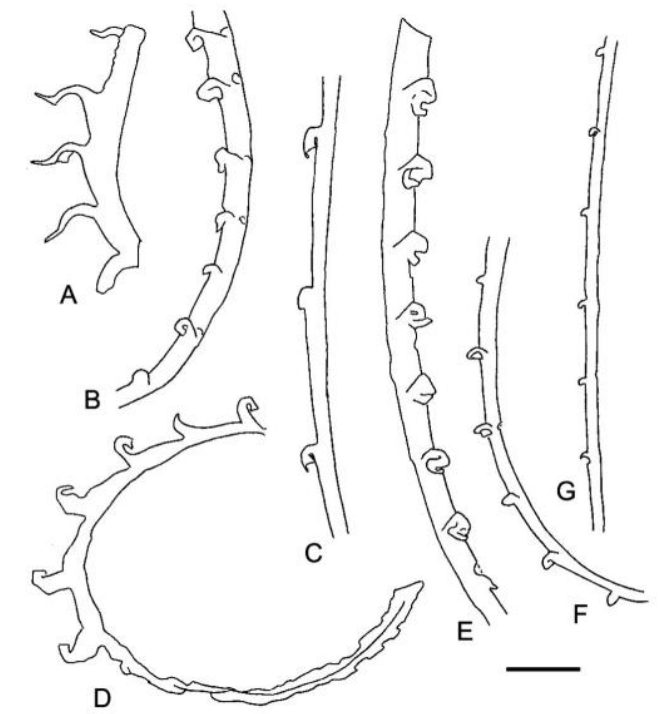

\section{Figure 10}

Selected Silurian graptolites from the Grötlingbo-1 core section. Scale bar represents $1 \mathrm{~mm}$. A. Oktavites spiralis (Geinitz), GIT XXX, sample G-1, 381.53-381.58 m. B. Streptograptus kaljoi Loydell, Männik \& Nestor, GIT XXX, sample C-22, 379.60-379.70 m. C. Mediograptus remotus (Elles \& Wood), GIT XXX, sample C-60, 340.23-340.35 m. D. Oktavites falx (Suess), GIT XXX, sample G-1, 381.53-381.58 m. E. Streptograptus nodifer (Törnquist), GIT XXX, sample G-2, 375.80-375.86 m. F. Mediograptus vittatus Šrorch, GIT XXX, sample C-56, 344.55-344.64 m. G. Mediograptus minimus (Bouček), GIT XXX, sample C-60, 340.23-340.35 m.

The lowest graptolite-bearing sample (G-1: $381.53-381.58 \mathrm{~m}$ ) is from just below sample C-20. The assemblage from sample G-1 includes Oktavites falx (Fig. 10: D) and O. spiralis (Fig. 10: A) and may be assigned to the $O$. spiralis GZ. The succeeding sample (C-22: 379.60-379.70 m) includes Streptograptus kaljoi (Fig. 10: B), indicating the lower part of the $O$. spiralis GZ; the next sample (G-2: 375.80-375.86 m) includes $O$. spiralis and Streptograptus nodifer (Fig. 10: E) indicating the middle or upper part of the O. spiralis GZ. O. spiralis is present also at $366.16 \mathrm{~m}(\mathrm{G}-4)$ in a pale mudstone, but with no other identifiable taxa, so this level is either still within the $O$. spiralis GZ or in the lower part of the succeeding Cyrtograptus lapworthi GZ.

A single distal Monoclimacis fragment, of very limited biostratigraphical significance, was present in sample C-55 (345.45-345.53 m). Above this, graptolites are more common with typical early Sheinwoodian assemblages present. Long-ranging taxa (Monograptus priodon, Monoclimacis geinitzii and Retiolites angustidens) are accompanied by stratigraphically useful Mediograptus species and fragments of robust Cyrtograptus (either C. centrifugus or C. murchisoni). Sample C-56 (344.55-344.64 m) includes Med. vittatus (Fig. 10: F), indicating the C. murchisoni GZ. The upper part of this biozone is indicated by the presence of Med. remotus (Fig. 10: C) in sample C-60 (340.23-340.35 m) where it is accompanied by Med. minimus (Fig. 10: G) another indicator of the $C$. murchisoni GZ. The highest sample (C-61: 339.31-339.44 m) contains abundant graptolites, but of long ranging species (M. priodon and Mcl. vomerina) only. 


\section{Stratigraphy}

\section{Ordovician}

The biostratigraphical data obtained enable recognition in the Grötlingbo-1 core section of most of the East Baltic regional stages. Some (unsampled) intervals are subdivided and correlated based on lithological considerations (Figs 2, 7).

In the lowermost part of the section, the Kukruse and Haljala stages are represented by pure light-grey limestone rich in black pyritic skeletal debris of the Adze Formation. The boundary between these stages is marked by disappearance of Conochitina tigrina (occurs in the uppermost Kukruse Stage only) and Laufeldochitina stentor below it, and the appearances of Angochitina curvata and abundant prasinophycean algae Leiosphaeridia sp. above it. In the studied section it lies between samples JN-19 and JN-20 (corresponds to the boundary between the Lauf. stentor and Ang. curvata CtZ-s). Characteristic of the Haljala Stage is the occurrence of Lagenochitina dalbyensis (Laufeld 1967; Nõlvak 2010 and references therein) appearing in the studied section about $3 \mathrm{~m}$ above the lower boundary of the stage. No change in lithology was observed at the stage boundary. In Sweden, lithologically identical strata, up to the Kinnekulle K-bentonite, are known as the Dalby Limestone (Formation).

The data above fit well with the conodont distribution in the section: samples JN-17 to JN-21 yielded faunas indicating the Baltoniodus gerdae $\mathrm{CZ}$, the middle part of the Amorphognathus tvaerensis CSZ. These conodont faunas suggest a mid Sandbian age for the interval and correlate the strata with the uppermost Kukruse to the lower Haljala stages in Estonia (Männik 2003; Männik \& Viira 2005).

A condensed interval ( $0.6 \mathrm{~m}$ thick), rich in leiosphaerids, above the Kinnekulle K-bentonite at $425.4 \mathrm{~m}$ evidently correlates with the Keila Stage in Estonia, where the Kinnekulle K-bentonite lies at (and marks) the base of the stage (Hints \& Nõlvak 1999; Bauert et al. 2014). Leiosphaerids are also very common in the Keila Stage in the East Baltic. The rarity of Spinachitina cervicornis, characteristic of the Keila Stage, in the Grötlingbo-1 core section results probably from pronounced silicification of the rock above the bentonite. The boundary between the Sandbian and Katian global stages lies in the interval 424.8-425.4 m, in the $0.6 \mathrm{~m}$ thick Keila Stage (Goldman et al., 2007).

Massive bioturbated silty marls in the interval 423.8-424.8 m (known as the Gräsgård Siltstone: Grahn \& Nõlvak 2010, text-fig. 10) have distinct impregnated discontinuity surfaces in their uppermost part (at 423.8, 424.0, 424.2 and $424.3 \mathrm{~m}$ ). Sharp lithological change at the base of the interval is marked by at least three very closely located surfaces with pyritic and/or phosphatic impregnation. Just above them, at the base of the marls, a thin conglomeratic interbed occurs. Ainsaar and Meidla (2001) have described similar silty marls in the East Baltic as the Variku Formation where, however, these beds have a stratigraphically wider range and correspond to the uppermost Keila and Oandu stages.

The chitinozoan assemblage from these marls in the Grötlingbo-1 core section (samples JN-14 and JN-15) is similar to that known from the Oandu Stage in Estonia. Specimens of Ancyrochitina bornholmensis (= 
Ancyrochitina sp. n. 1 in Nõlvak \& Grahn 1993) occurring also in sample JN-15 can sometimes be almost identical to small specimens of Spin. cervicornis (Vandenbroucke et al. 2013). For that reason both taxa in sample JN-15 are identified as "cf.".

In the uppermost part of the interval $423.8-424.8 \mathrm{~m}$, between distinct discontinuity surfaces at 423.8 and 424.0 $\mathrm{m}$, in sample JN-13, Belonechitina cf. robusta was found. These specimens are morphologically very similar to the typical B. robusta characteristic of an interval from the topmost Keila to the topmost Rakvere Stage in Estonia. However, all of our specimens lack the spines typical of B. robusta (removed during recrystallization of the rock?). The occurrence of Belonechitina cf. robusta together with lithological considerations (below) suggest correlation of this interval with the Tõrremägi Member (lowermost Rägavere Fm.) in Estonia. Lithologically, this member is transitional between the marls below and limestone above, in both the Grötlingbo-1 core section and in North Estonia where the Tõrremägi Member lies between marls of the Hirmuse Fm. and micritic limestones of the Rägavere Fm. (Nõlvak 1997).

Conodonts are very rare in these strata. Only one of the three samples from this interval contained conodonts: in sample JN-14 (424.12-424.17 m) a single specimen of Panderodus panderi was found. However, a sample just below this interval (sample JN-16: 425.10-425.15 m) yielded a probable fragment of Amorphognathus sp. Based on data from Estonia (Männik 2003; Männik \& Viira 2005) a considerable decline in the abundance of conodont specimens and number of taxa in the upper Sandbian-lower Katian interval was caused by the MidCaradoc Event (Männik 2004). A single probable fragment of Amorphognathus in the sample JN-16 might suggest that the sample comes already from the upper part (above Datum 3 sensu Männik 2004) of the event and, hence, also this level might correspond to the Oandu Stage in Estonia.

The next set of samples comes from the interval 420.3-425.4 m (samples JN-9 to JN-12), according to the Swedish nomenclature from the upper Slandrom Limestone. In the sections in South Estonia stratigraphical equivalents of this unit include two different lithologies: the dense nodular micritic limestones of the Rägavere Fm. below and the glauconite-bearing calcarenites with numerous phosphatic discontinuity surfaces of the Mõntu Fm. above. In the Grötlingbo-1 core section, the boundary between these formations is marked by a discontinuity surface at $421.7 \mathrm{~m}$. Just below this level, in sample JN-12 (421.87-421.93 m) Fungochitina spinifera appears indicating that the lower boundary of the Fung. spinifera $\mathrm{CtZ}$ lies below this level. In Estonia, the lower boundary of this zone corresponds to a level in the upper Oandu Stage. A rich, diverse chitinozoan assemblage appears in sample JN-11 in the Grötlingbo-1 section. Similar rapid chitinozoan radiation characterizes the boundary beds between the Rakvere and Nabala stages in many sections in Estonia (Nõlvak 2010 and references therein). As a rule, chitinozoans are well preserved, often three-dimensionally, in these strata. Characterisric of the Mõntu Fm. are Cyathochitina kuckersiana, Cy. campanulaeformis, Cy. costata (Grahn 1982) and Cy. patagiata (often represented by morphologically transitional forms which might complicate identification of these species considerably). In many East Baltic sections, the base of the Nabala Stage is marked by the appearance of Armoricochitina reticulifera. Conodonts suggest the Amorphognathus superbus $\mathrm{CZ}$ for the upper Slandrom Formation. In Estonia, this zone corresponds to the interval from the upper Oandu to the upper Nabala stages (=middle Katian). It is noteworthy that in the Grötlingbo-1 core section 
a K-bentonite occurs at $421.4 \mathrm{~m}$, in the interval corresponding to the Nabala Stage in the East Baltic where no $\mathrm{K}$-bentonite is known from this interval.

The strata corresponding to the Keila, Oandu, Rakvere and Nabala stages have strongly reduced thicknesses in the Grötlinbo-1 core section. Lithological evidence (sharp lithological boundaries, abundant discontinuity surfaces) indicate that a number of gaps occurs in this interval. However, the duration of these gaps is less than the biostratigraphical resolution currently available. The restricted thickness of beds in this interval is characteristic of several sections located in the western Estonia: Ruhnu-5000 (Põldvere 2003), Viki (Nõlvak 2010), Kaugatuma, Ohesaare (J. Nõlvak, unpubl. data), etc.

Based on lithology, the strata above are tentatively assigned to the Tudulinna Formation (to the Fjäcka Fm. in Grahn \& Nõlvak 2010) of the Vormsi Stage (interval 415.4-420.3 m) and to the Jonstorp Formation of the Pirgu Stage (interval 405.0-415.4 m). The earlier assignment of rocks in the former interval to the Fjäcka Formation appeared to be problematical - no beds of black bituminous shales (or even laminae of them) characteristic of the formation were recorded in the Grötlingbo-1 section. Instead, the greenish-grey mudstone in the interval is most similar to that of the Tudulinna Fm. in Estonia. The only sample from the base of the Tudulinna Fm. (JN-8) yields conodonts but not chitinozoans. Amorphognathus ordovicicus in the sample indicates that the boundary between the Am. superbus and Am. ordovicicus CZ-s in the section lies in the interval 420.20-420.45 m. In Estonia, the oldest record of Am. ordovicicus comes from the upper Nabala Stage (Männik \& Viira 2005). Based on some earlier data, Acanthochitina barbata, known to occur in the upper Vormsi Stage in the East Baltic sections (Calner, Lehnert \& Nõlvak 2010), has been found in the upper part of the Tudulinna Fm. in the Grötlingbo-1 core section (Fjäcka Fm. Grahn \& Nõlvak 2010).

Lithological data suggest that only lower part of the Pirgu Stage is represented in the section: the red-coloured marlstone and argillaceous limestone of the Jonstorp Formation are directly followed by intercalations of grey silty calcareous marlstones and limestones with rare bioclasts of the Tommarp Formation (Grahn \& Nõlvak 2010). A similar lithological succession, red-coloured rocks of the Jonstorp Fm. directly followed by strata of Porkuni age, has been recorded in the Ruhnu-500 core section in SW Estonia (Põldvere 2003) and in the Stirnas-18 core section in western Latvia (Hints et al. 2010).

Samples from the uppermost Ordovician interval in the Grötlingbo-1 core section yield rare, poorly preserved specimens of Cyathochitina campanulaeformis and Ancyrochitina ancyrea, both of which occur also in the lower(most) Silurian. The occurrence of Am. ordovicicus in sample C-62 (397.50-397.60 m) indicates that this level still corresponds to the Am. ordovicicus $\mathrm{CZ}$. Based on the data from more complete sections from the central part of the basin, from the Ruhnu-500 (Estonia) and Stirnas-18 (western Latvia) core sections, Am. ordovicicus (together with several taxa characteristic of the Am. ordovicicus CZ) disappears in the lower part of the Porkuni Stage (lower part of the Hirnantian; Männik 2003; Hints et al. 2010). In these sections, the uppermost part of the stage is characterized by poor faunas dominated by Noixodontus. In the Grötlingbo-1 core section Noixodontus has not been found. Instead, the sample just above a distinct lithological change at 
397.05 m yields taxa typical of lower Llandovery (see below). These data suggest that a gap corresponding at least to the upper Porkuni Stage (=to the upper Hirnantian) exists in the Grötlingbo-1 core section.

\section{Silurian}

The Distomodus kentuckyensis CZ, and Ancyrochitina laevaensis and Belonechitina postrobusta CtZ-s in the lower part of the Silurian succession in the Grötlingbo-1 core section indicate that this interval corresponds to the Juuru Stage in Estonia (Figs. 3, 9). The boundary between the Juuru and Raikküla stages is tentatively correlated with the level $(386.6 \mathrm{~m})$ at which limestone is replaced by argillaceous marlstone in the section. The boundary is poorly constrained biostratigraphically but the occurrence of the Aspelundia? expansa $\mathrm{CZ}$ and Spinachitina maennili $\mathrm{CtZ}$ faunas in strata above this level indicates a Raikküla (late Rhuddanian-Aeronian) age for these strata.

The Spin. maennili $\mathrm{CtZ}$ is directly overlain by an Ang. longicollis $\mathrm{CtZ}$ fauna and the Asp.? expansa $\mathrm{CZ}$ is followed by a Pterospathodus amorphognathoides angulatus (=lower Pt. celloni CSZ) assemblage indicating a gap of considerable duration in the section. The gap corresponds to the upper Aeronian-lower Telychian interval: in the conodont succession to the interval from the middle Asp.? expansa up to the Pt. am. angulatus CZ-s (Fig. 11). In the chitinozoan succession, Ancyrochitina convexa, Conochitina alargada and Eisenackitina dolioliformis CtZ-s are missing. This parallels the situation in the När core, SE Gotland, recorded by Grahn (1995), where the Oktavites spiralis GZ is also shown immediately overlying the lower Aeronian. The presence of the Pt. am. angulatus $\mathrm{CZ}$ and Ang. longicollis $\mathrm{CtZ}$ in the strata immediately above the unconformity in the Grötlingbo-1 core, together with the occurrence here of Oktavites spiralis indicate that the sedimentary record in the core recommences in the lower part of the O. spiralis GZ. A gap of about similar duration has been recognised earlier in several other sections in the East Baltic (Nestor 2012). The gap in the Grötlingbo-1 core section is far more extensive than in the Ohesaare section (Loydell, Kaljo \& Männik 1998), within the same facies belt, where the gap in the succession is from the lower Aeronian through to the lower Telychian Spirograptus turriculatus GZ, in conodont biostratigraphical terminology from the (lower) Asp.? expansa CZ up to the Pt. eopennatus ssp. n. $1 \mathrm{CZ}$. 


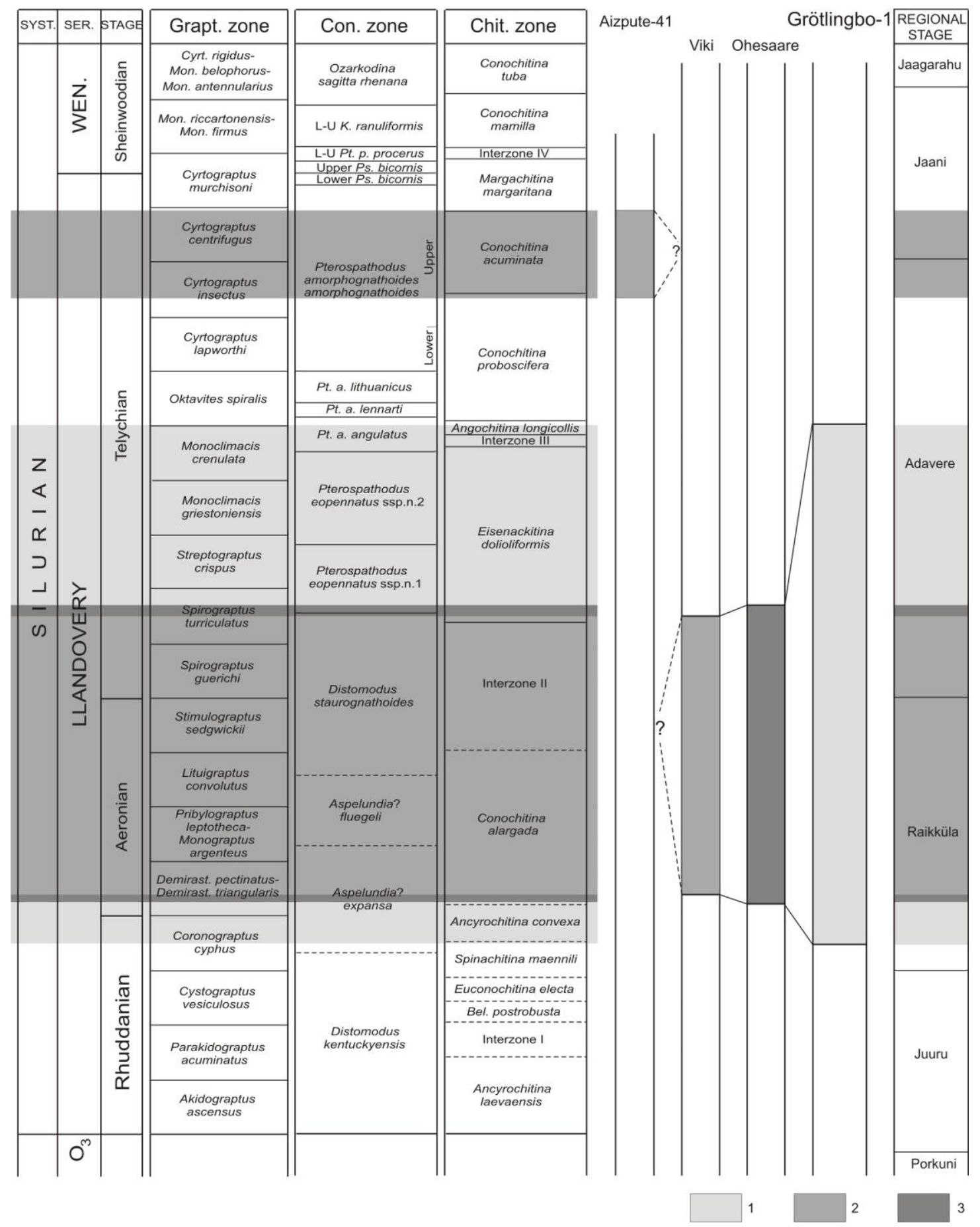

\section{Figure 11}

Dated gaps in the Llandovery in some core sections. Correlation of the graptolite and conodont zonations is modified from Cramer et al. 2011; the chitinozoan zonation is based mainly on data from Loydell, Kaljo \& Männik 1998, Loydell, Männik \& Nestor 2003 and Loydell, Nestor \& Männik 2010. Two unnamed chitinozoan zones between the Eisenackitina dolioliformis (below) and Conochitina proboscifera (above) CtZ-s correspond (from below) to Interzone III and the Angochitina longicollis CtZ. Dating of regional stages in Estonia (right column) follows Männik (2014). Abbreviations: Syst. - System; Ser. - Series; grapt. - graptolite; con. - conodont; chit. - chitinozoan; Cyrt. - Cyrtograptus; Mon. Monograptus; Monocl. - Monoclimacis; Str. - Streptograptus; Spir. - Spirograptus; Stim. - Stimulograptus; Lit. Lituigraptus; Pri. - Pribylograptus; Demirast. - Demirastrites; Coron. - Coronograptus; Cyst. - Cystograptus; Parak. Parakidograptus; Akid. - Akidograptus; Oz. - Ozarkodina; L - Lower; U - Upper; K. Kockelella; Pt. -Pterospathodus; . - pennatus; Ps. - Pseudooneotodus; a. - amorphognathoides; Marg. - Margachitina; Bel. - Belonechitina.

Complete conodont and chitinozoan zonal successions suggest that the strata above the main gap in the Grötlingbo-1 core section are evidently complete. Problems related to the identification of Pt. am. lennarti and Pt. am. lithuanicus CZ-s in the upper part of the Pt. celloni CSZ are caused by ecological reasons: both taxa are very rare and occur sporadically in distal environments (Männik 1998; Loydell, Männik \& Nestor 2003; 
Loydell, Nestor \& Männik 2010). The few graptolites available indicate that the interval between $375.80 \mathrm{~m}$ and $381.58 \mathrm{~m}$ corresponds to the $O$. spiralis GZ. Graptolites from about $1 \mathrm{~m}$ below the lower boundary of the Pt. am. amorphognathoides $\mathrm{CZ}$ in the section come from either the upper $O$. spiralis $\mathrm{GZ}$ or from the lower Cyrtograptus lapworthi GZ. This agrees with earlier data suggesting correlation between the lower boundaries of the Cyrt. lapworthi GZ and Pt. am. amorphognathoides CZ (Loydell, Kaljo \& Männik 1998; Loydell, Männik \& Nestor 2003).

Graptolites become common above sample C-55, above the K-bentonite (345.8 $\mathrm{m}$ ) at the base of dark-coloured claystones and silty claystones above (Fig. 4). Sample C-56 from the upper part of the Upper Pt. am. amorphognathoides Conodont Subzone (from the lowermost Margachitina margaritana CtZ) comes from the Cyrt. murchisoni GZ. Sample C-60 yields graptolites characteristic of the upper Cyrt. murchisoni GZ. The highest sample in the section (C-61) contains abundant but long ranging species of graptolites only. The composition of, and changes in the conodont assemblages in samples C-58 to C-61 suggests that these four samples come from the Ireviken Event interval. As the uppermost sample studied comes from the Lower $K$. ranuliformis $\mathrm{CZ}$ it is evident that the uppermost part of the event lies above the interval studied by us. Based on the data from the Aizpute-41 core section, the boundary between the Pt. pennatus procerus and K. ranuliformis CSZ-s correlates with the boundary between the Monograptus firmus and M. riccartonensis GZ-s (Loydell, Männik \& Nestor 2003). Hence, the uppermost sample studied from the Grötlingbo-1 core section is probably younger than the Cyrt. murchisoni GZ. The occurrence of graptolites characteristic of the upper Cyrt. murchisoni GZ in the Ireviken Event interval agrees with earlier data (Männik 2007a) that the Ireviken Event correlates with the upper part of the Cyrt. murchisoni GZ (and higher stratigraphical levels).

Datum 2 of the event (corresponding to the Llandovery-Wenlock boundary in its type section at Hughley Brook) cannot be identified in the Grötlingbo-1 core section but, based on the data available (above), it most probably lies between samples C-58 and C-60.

The strata above the main gap in the Aeronian-Telychian transition in the section, up to the uppermost Pt. am. amorphognathoides $\mathrm{CZ}$ (up to the M. banwyensis $\mathrm{CtZ}$ ), correlate with the Adavere Stage in Estonia. The boundary between the Adavere and overlying Jaani stages is poorly dated biostratigraphically. In its type section, in the Ohesaare core, the boundary was established at $345.8 \mathrm{~m}$ and is marked here by a K-bentonite (Aaloe 1970). At the same level greenish grey to grey marlstone are replaced by dark (brownish) grey claystone and silty claystone. Based on similarities of faunal and lithological successions in the Ohesaare and Grötlingbo1 core sections, the boundary between the Adavere and Jaani stages in the Grötlingbo- 1 core section is tentatively considered to correspond to the K-bentonite at $345.8 \mathrm{~m}$. At the same level argillaceous marlstones are replaced by dark-coloured silty claystones also in this section. 


\section{Conclusions}

The biostratigraphical data obtained enable recognition in the Grötlingbo-1 core section of most of the regional stages known from the Sandbian (Upper Ordovician) to lower Sheinwoodian (Wenlock, Silurian) interval in the East Baltic.

The strata corresponding to the Keila, Oandu, Rakvere and Nabala stages have strongly reduced thicknesses in the Grötlingbo-1 core section. Lithological evidence (sharp lithological boundaries, abundant discontinuity surfaces) indicate that a number of gaps occurs in this interval. However, the duration of these gaps is below the biostratigraphical resolution currently available.

Based on lithological evidence, only lower part of the Pirgu Stage (corresponding to the Jonstorp Fm. or to part of it) is represented in the section.

A gap corresponding at least to the upper Porkuni Stage (=to the upper Hirnantian) exists in the Grötlingbo-1 core section.

The strata corresponding to the Asp.? fluegeli and Distomodus staurognathoides CZ-s, and to the Pterospathodus eopennatus CSZ, in the conodont succession, and to the Conochitina alargada and Eisenackitina dolioliformis CtZ-s in the chitinozoan succession, are missing in the studied section. The presence of the Pt. amorphognathoides angulatus $\mathrm{CZ}$ and Angochitina longicollis $\mathrm{CtZ}$ in the strata immediately above the unconformity in the Grötlingbo-1 core, together with the occurrence here of Oktavites spiralis indicate that the sedimentary record in the core recommences in the lower part of the O. spiralis GZ.

Graptolites about $1 \mathrm{~m}$ below the lower boundary of the Pt. am. amorphognathoides $\mathrm{CZ}$ in the section come from either the upper $O$. spiralis $\mathrm{GZ}$ or from the lower Cyrtograptus lapworthi $\mathrm{GZ}$. This agrees with earlier data suggesting correlation between the lower boundaries of the Cyrt. lapworthi GZ and Pt. am. amorphognathoides $\mathrm{CZ}$.

Occurrence of graptolites characteristic of the upper Cyrt. murchisoni GZ in the Ireviken Event interval agrees with earlier data that (part of) the Ireviken Event correlates with the upper Cyrt. murchisoni GZ.

Acknowledgements - PM and JN are grateful to late Prof. Maurits Lindström and to Dr Stefan Hagenfeldt who provided access to the Grötlingbo-1 core section and helped us during sampling. The study was supported by Estonian Research Council grants No-s 8907, 9039 and PUT378. 


\section{References}

Aaloe, A. 1970. Jaani Stage. In D. Kaljo (ed.): The Silurian of Estonia, 343-250. Valgus, Tallinn. [In Russian with English summary]

Ainsaar, L. \& Meidla, T. 2001. Facies and stratigraphy of the middle Caradoc mixed siliciclastic-carbonate sediments in eastern Baltoscandia. Proceedings of the Estonian Academy of Sciences, Geology 50, 5-23.

Bauert, H., Isozaki, Y., Holmer, L. E., Aoki, K., Sakata, S. \& Hirata, T. 2014. New U-Pb zircon ages of the Sandbian (Upper Ordovician) „Big K-bentonite” in Baltoscandia (Estonia and Sweden) by LA-ICPMS. GFF 136, 30-33.

Calner, M., Lehnert, O. \& Nõlvak, J. 2010. Palaeokarst evidence for widespread regression and subaerial exposure in the middle Katian (Upper Ordovician) of Baltoscandia: Significance for global climate. Palaeogeography, Palaeoclimatology, Palaeoecology 296, 235-247.

Cramer, B.D., Brett, C.E., Melchin, J.M., Männik, P., Kleffner, M.A., McLaughlin, P.I., Loydell, D.K., Munnecke, A., Jeppsson, L., Corradini, C., Brunton, F.R. \& Saltzman, M.R. 2011. Revised correlation of Silurian Provincial Series of North America with global and regional chronostratigraphic units and $\delta^{13} \mathrm{C}_{\text {carb }}$ chemostratigraphy. Lethaia 44, 185-202.

Ebbestad, J. O. R. \& Högström, A. E. S. 2007. Ordovician of the Siljan District, Sweden. WOGOGOB 2007, Field guide and Abstracts. SGU Rapporter och meddelanden 128, 7-26.

Eriksson, K. \& Hagenfeldt, S. E., 1997. Acritarch assemblages from the Lower Silurian (Llandovery-Wenlock) in the Grötlingborrningen 1 core, Gotland, Sweden. GFF 119, 13-16.

Goldman, D., Leslie, S. A., Nõlvak, J. \& Young, S. 2007. The Black Knob Ridge section, southeastern Oklahoma, USA: the Global Stratotype-Section and Point (GSSP) for the base of the Katian Stage of the Upper Ordovician Series. Acta Palaeontologica Sinica 46 (Suppl.), 144-154.

Grahn, Y. 1982. Caradocian and Ashgillian Chitinozoa from the subsurface of Gotland. Sveriges Geologiska Undersökning Serie C 788, 1-66.

Grahn, Y. 1995. Lower Silurian Chitinozoa and biostratigraphy of subsurface Gotland. GFF 117, 57-65.

Grahn, Y. \& Nõlvak, J. 2010. Swedish Ordovician Chitinozoa and biostratigraphy: a review and new data. Palaeontographica, Abteilung B 283, 5-71. 
Hints, L., Hints, O., Kaljo, D., Kiipli, T., Männik, P., Nõlvak, J. \& Pärnaste, H. 2010. Hirnantian (latest Ordovician) bio- and chemostratigraphy of the Stirnas-18 core, western Latvia. Estonian Journal of Earth Sciences 59, 1-24.

Hints, O. \& Nõlvak, J. 1999. Proposal for the lower boundary-stratotype of the Keila Regional Stage (Upper Ordovician). Proceedings of the Estonian Academy of Sciences. Geology 48, 158-165.

Jaanusson,V. 1976. Faunal dynamics in the Middle Ordovician (Viruan) of Balto-Scandia. In M. G. Bassett (ed.): The Ordovician System: Proceedings of a Palaeontological Association Symposium, 301326. University of Wales Press, Cardiff.

Jeppsson, L. 1997. A new latest Telychian, Sheinwoodian and Early Homerian (Early Silurian) standard conodont zonation. Transactions of the Royal Society of Edinburgh: Earth Sciences 88, 91-114.

Jeppsson, L. \& Männik, P. 1993. High-resolution correlations between Gotland and Estonia near the base of the Wenlock. Terra Nova 5, 348-358.

Kaljo, D. \& Jürgenson, E. 1970. Sedimentary facies of the East Baltic Silurian. In D. Kaljo (ed.): Facies and fauna of the Baltic Silurian, 122-148. Academy of Sciences of the Estonian S.S.R, Tallinn.

Kjellström, G. 1971a. Ordovician microplankton (Baltisphaerids) from the Grötlingbo borehole no. 1 in Gotland, Sweden. Sveriges Geologiska Undersökning Series C 655, 5-75.

Kjellström, G. 1971b. Middle Ordovician microplankton from the Grötlingbo borehole no.1 in Gotland, Sweden. Sveriges Geologiska Undersökning Series C 669, 5-35.

Laufeld, S. 1967. Caradocian Chitinozoa from Dalarna, Sweden. Geologiska Föreningens I Stockholm Förhandlingar 89, 275-349.

Loydell, D. K., Kaljo, D. \& Männik, P. 1998. Integrated biostratigraphy of the lower Silurian of the Ohesaare core, Saaremaa, Estonia. Geological Magazine 135, 769-783.

Loydell, D. K., Männik, P. \& Nestor, V. 2003. Integrated biostratigraphy of the lower Silurian of the Aizpute-41 core, Latvia. Geological Magazine 140, 205-229.

Loydell, D. K. \& Nestor, V. 2005. Integrated graptolite and chitinozoan biostratigraphy of the upper Telychian (Llandovery, Silurian) of the Ventspils D-3 core, Latvia. Geological Magazine 142, 369-376.

Loydell, D. K., Nestor, V. \& Männik, P. 2010. Integrated biostratigraphy of the lower 
Silurian of the Kolka-54 core, Latvia. Geological Magazine 147, 253-280.

Melchin, M. J., Sadler, P. M. \& Cramer, B. D. 2012: The Silurian Period. In Gradstein, F. M., Ogg, J. G., Schmitz, M. D. \& Ogg, G. M. (eds): The Geologic Time Scale 2012. Volume 1, 525-558. Elsevier.

Mullins, G. L. \& Aldridge, R. J. 2004. Chitinozoan biostratigraphy of the basal Wenlock Series (Silurian) global stratotype section and point. Palaeontology 47, 745-773.

Männik, P. 1998. Evolution and taxonomy of the Silurian conodont Pterospathodus. Palaeontology 41, 10011050.

Männik, P. 2003. Distribution of Ordovician and Silurian conodonts. In A. Põldvere (ed.): Ruhnu (500) drill core. Estonian Geological Sections 5, 17-23.

Männik, P. 2004. Recognition of the Mid-Caradoc Event in the conodont sequence of Estonia. In O. Hints \& L. Ainsaar (eds), WOGOGOB-2004 Conference Materials pp. 63-64. Tartu University Press, Tartu.

Männik, P. 2007a. Some comments on the Telychian-early Sheinwoodian conodont faunas, events and stratigraphy. Acta Palaeontologica Sinica 46 (Suppl.), 305-310.

Männik, P. 2007b. An updated Telychian (Late Llandovery, Silurian) conodont zonation based on Baltic faunas. Lethaia 40, 45-60.

Männik, P. 2014. The Silurian System in Estonia. In H. Bauert, O. Hints, T. Meidla \& P. Männik (eds): $4^{\text {th }}$ Annual Meeting of IGCP 591, Estonia, 10-19 June 2014. Abstracts and Field Guide, 123-128. University of Tartu, Tartu.

Männik, P. \& Viira, V. 2005. Distribution of Ordovician conodonts. In A. Põldvere (ed.): Mehikoorma (421) drill core. Estonian Geological Sections 6, 16-20

Männil, R. 1990. The Ordovician of Estonia. In D. Kaljo \& H. Nestor (eds): Field Meeting Estonia 1990. An Excursion Guidebook, 11-20. Estonian Academy of Sciences, Tallinn.

Nestor, V. 1994. Early Silurian chitinozoans of Estonia and north Latvia. Academia 4, 1-163.

Nestor, V. 2012. A summary and revision of the East Baltic Silurian chitinozoan biozonation. Estonian Journal of Earth Sciences 61, 242-260.

Nõlvak, J. 1997. Ordovician. Introduction. In A. Raukas \& A. Teedumäe (eds): Geology and mineral resources of Estonia, 54-55. Estonian Academy Publishers, Tallinn. 
Nõlvak, J. 2010. Distribution of Ordovician chitinozoans. In A. Põldvere (ed.): Viki drill core. Estonian Geological Sections 10, 17-18

Nõlvak, J. \& Grahn, Y. 1993. Ordovician chitinozoan zones from Baltoscandia. Review of Palaeobotany and Palynology 79, 245-269.

Nõlvak, J., Hints, O. \& Männik. P. 2006. Ordovician timescale in Estonia: recent developments. Proceedings of the Estonian Academy of Sciences. Geology 55, 95-108.

Põldvere, A. (ed.) 2003. Ruhnu (500) drill core. Estonian Geological Sections 5, 1-76.

Snäll, 1977. Silurian and Ordovician bentonites of Gotlnad (Sweden). Stockholm Contributions in Geology 31, $1-80$.

Vandenbroucke, T. R. A., Recourt, P., Nõlvak, J. \& Nielsen, A. 2013. Chitinozoan biostratigraphy of the Upper Ordovician D. clingani and P. linearis graptolite biozones on the Island of Bornholm, Denmark. Stratigraphy $10,281-301$. 